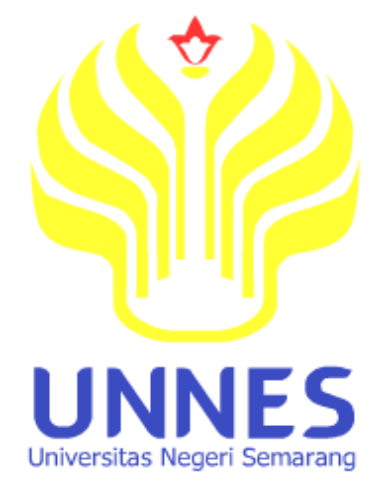

\title{
KAJIAN PSIKOLOGI PARA PEMAIN BAND SAKADATHU DALAM MUSIK CLUB MALAM DI LIQUID SEMARANG
}

\section{SKRIPSI}

untuk memperoleh gelar Sarjana Pendidikan

$\begin{array}{ll} & \text { Oleh } \\ \text { Nama } & : \text { Ajeng Adhadiantin } \\ \text { NIM } & : 2501409068 \\ \text { Program Studi } & : \text { Pendidikan Seni Musik } \\ \text { Jurusan } & : \text { Pendidikan Seni, Drama, Tari dan Musik }\end{array}$

FAKULTAS BAHASA DAN SENI

UNIVERSITAS NEGERI SEMARANG

2016 


\section{PERSETUJUAN BIMBINGAN}

Skripsi dengan judul "Kajian Psikologi Para Pemain Band Sakadathu Dalam Musik Club Malam Di Liquid Semarang" telah disetujui oleh Dosen Pembimbing dan akan diajukan ke sidang Panitia Ujian Skripsi, Jurusan Pendidikan Seni Drama Tari dan Musik, Fakultas Bahasa dan Seni, Universitas Negeri Semarang.

Semarang, 25 Februari 2016

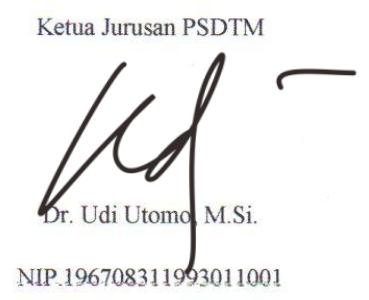

Dosen Pembimbing I

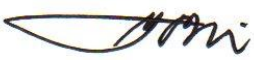

Drs. Suharto, S.Pd., M.Hum

NIP. 196510181990031002
Dosen Pembimbing II

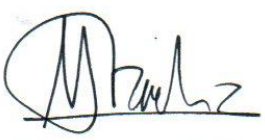

Abdul Rachman, S.Pd,M.P

NIP. 198001202006041002 
PENGESAHAN KELULUSAN

Skripsi ini telah dipertahankan di hadapan siding Panitia Ujian Skripsi Jurusan Seni Drama, Tari dan Musik, Fakultas Bahasa dan Seni, Universitas Negeri Semarang
Pada Hari : : Rabu
Tanggal $\quad: 23$ Maret 2016
Panitia Ujian Skripsi

1. Ketua

Prof. Dr. Subyantoro, M.Hum.

NIP 196802131992031002

2. Sekretaris

Dra. Malarsih, M.Sn

196106171988032001

3. Penguji I

Drs. Suharto, S.Pd., M.Hum

196510181990031002

4. Penguji II

Abdul Rachman, S.Pd., M.Pd.

198001202006041002

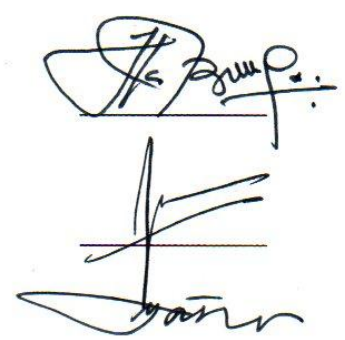

. Penguji III/ Pembimbing

Drs. Moh. Muttaqin, M.Hum

NIP 196504251992031001

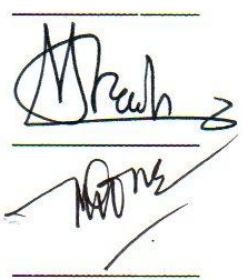

Dekan Fakultas Bahasa dan Seni

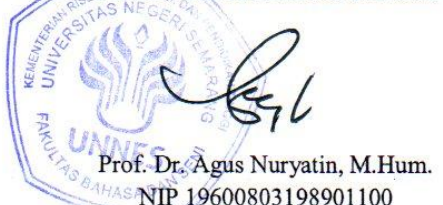

NIP 19600803198901100 
PERNYATAAN

Saya menyatakan bahwa yang tertulis di dalam skripsi ini benar-benar hasil karya saya sendiri, bukan jiplakan dari karya orang lain, sebagian atau seluruhnya Pendapat atau temuan orang lain yang terdapat dalam skripsi ini dikutip atau dirujuk berdasarkan kode etik ilmiah.

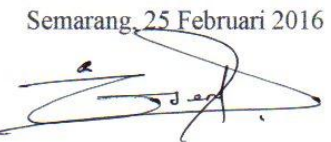

Ajeng Adhadiantin

21501409068 


\section{MOTTO DAN PERSEMBAHAN}

\section{MOTTO}

Kebanyakan dari kita tidak mensyukuri apa yang sudah kita miliki, tetapi kita selalu menyesali apa yang belum kita capai (Schopenhauer).

Tuntutlah ilmu, tapi tidak melupakan ibadah dan kerjakanlah ibadah tetapi tidak melupakan ilmu (Hasan Al-Bashri).

\section{PERSEMBAHAN}

Skripsi ini penulis persembahkan kepada:

1. Keluarga tercinta

Ayahanda Wasno Sujitno, Ibunda Hardatin, dan saudara-saudara kandungku Diah Purnama Wati, Arif Wiradianto, Mikyal Tejawati, Adinda Purnama Syane, Kamal Attallah

2. Teman-teman Tersayang Rahmatditya Bondan, Ian Romadhon, Frenty Febby, Amelia Dwi Aryantika, Sela, Bonci, Boim

3. Teman-Teman Sendratasik Inka, Nia, Nindy, Ninda, Rita, Cindy, Emah

4. Pembaca Budiman 


\section{KATA PENGANTAR}

Puji syukur penulis panjatkan kehadirat Allah SWT yang telah melimpahkan rahmat, hidayah, serta karunia-Nya kepada penulis untuk menyusun skripsi dengan judul Kajian Psikologi Para Pemain Band Sakadathu Dalam Musik Club Malam Di Liquid Semarang sebagai syarat untuk mencapai gelar Sarjana Pendidikan Seni Musik Fakultas Bahasa dan Seni UNNES sehingga dapat terselesaikan dengan baik.

Penulis menyadari penyelesaian skripsi ini tidak terlepas dari bantuan dan dukungan dari berbagai pihak yang sangat berguna bagi penulis. Oleh karena itu dengan penuh kerendahan hati perkenankanlah penulis mengucapkan terima kasih kepada:

1. Prof. Dr. Fathur Rohman, M. Hum., Rektor Universitas Negeri Semarang yang telah memberikan kesempatan bagi penulis untuk memperoleh pendidikan formal di UNNES sehingga penelitian ini dapat dilaksanakan dengan baik.

2. Prof. Dr. Agus Nuryatin, M.Hum., Dekan Fakultas Bahasa dan Seni Universitas Negeri Semarang yang telah memberikan ijin dalam penelitian ini.

3. Dr Udi Utomo, M.Si, Ketua Jurusan Pendidikan Sendratasik yang telah memberikan kepercayaan kepada penulis untuk melakukan penelitian.

4. Drs. Suharto, S.Pd., M.Hum., Dosen Pembimbing I yang telah memberikan bimbingan, pengarahan dan dukungan penuh dalam kesempurnaan penyusunan skripsi ini. 
5. Abdul Rachman, S.Pd, M.Pd., selaku Dosen Pembimbing II yang telah memberikan bimbingan, pengarahan dan dukungan penuh dalam kesempurnaan penyusunan skripsi ini.

6. Manager Liquid Café Semarang yang telah memberikan ijin dan fasilitas kepada penulis selama mengadakan penelitian.

7. Band Sakadathu Semarang yang telah membantu selama pelaksanaan penelitian.

Penulis menyadari masih banyak kekurangan dalam skripsi ini, oleh karena itu kritik dan saran yang membangun sangat penulis harapkan. Semoga skripsi ini dapat memberikan manfaat bagi penulis dan para pembaca.

Semarang,10 Februari 2016

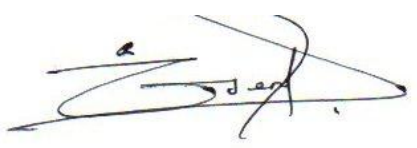

Penulis 


\begin{abstract}
ABSTRAK
Adhadiantin, Ajeng, 2015. Kajian Psikologi Para Pemain Band Sakadathu Dalam Musik Club Malam Di Liquid Semarang. Skripsi. Jurusan Pendidikan Seni Drama Tari dan Musik. Universitas Negeri Semarang, Pembimbing 1: Drs. Suharto, S.Pd., M.Hum., Pembimbing 2: Abdul Rachman, S.Pd,M.Pd

Kata kunci: Psikologi, Gaya Hidup, Gaya Bermusik

Sakadathu merupakan salah satu band RnB populer yang sering menjadi homeband club malam di Semarang, salah satunya di Liquid Semarang. Musik keras, penonton rusuh, alkohol, pergaulan bebas sering terjadi dalam lingkungan club malam Liquid. Pengontrolan diri yang baik dibutuhkan para pemain band Sakadathu. Pengaruh dari lingkungan kalangan atas membuat gaya hidup salah satu pemain Sakadathu menjadi hedonis. Masalah penelitian ini adalah bagaimanakah psikologi para pemain band Sakadathu dalam musik club malam Liquid Semarang dilihat dari gaya hidup dan gaya bermusiknya. Tujuan untuk mengetahui dan mendeskripsikan psikologi para pemain band Sakadathu.

Penelitian ini menggunakan metode penelitian kualitatif dengan memaparkan hasil penelitian secara deskriptif. Teknik pengumpulan data yang digunakan dalam penelitian ini adalah observasi, wawancara, dokumentasi, dan studi pustaka. Teknik analisis penelitian ini terbagi dalam tiga tahap yaitu reduksi data, penyajian data, menarik kesimpulan.

Sakadhatu terbentuk November 2011. Sakadathu pondasi, dalam mereka bermusik dan memilih nama yang unik menjadikan mereka lebih unggul dibandingkan dengan band pesaing mereka meskipun mereka sama-sama membawakan musik R\&B sebagai aliran mereka bermusik. Sakadhatu beranggotakan Inu(drum), Pungky (bass), Adhi ( gitar), Vientan (keyboard), Dino, Girda, Helga (vokal). Konsep utama mereka sejak terbentuk adalah menjadi sebuah band longtrip yang solid, hingga saat ini Palu, Samarinda, dan Semarang, , Hard Rock Cafe Bali, menjadi motifasi mereka untuk terus berkembang dan menjadi band yang lebih baik. Psikologi pemain band Sakadathu dalam musik dunia malam dilihat dari gaya bermusik cukup fleksibel, tiap pemain mempunyai karakter diri dan karakter musik yang berbeda. Tetapi mereka saling melengkapi untuk menutupi kekurangan dalam diri masing-masing. Intigritas yang tinggi pada pekerjaannya dan memiliki sikap kesetiakawanan antar sesama anggota band. Dilain sisi Sakadathu terbilang kurang stabil dilihat dari gaya hidup. Lingkungan sehari-hari yang berinteraksi dengan kalangan atas dunia malam, hidupnya cederung menjadi boros dan hedonis.

Anggota band sakadhatu khususnya vokalis mengutamakan keselamatan dirinya dalam menghibur pengunjung dengan menjaga jarak aman dari jangkauan penunton saat penguasaaan panggung sehingga pengunjung tetap terhibur dan para personil khususnya vokalis tetap aman terkendali. Melihat fakta bahwasanya bekerja didunia musik tidak selamanya stabil,sebaiknya pemain band Sakadathu mulai membatasi pergaulan dengan kalangan yang kurang menguntungkan untuk diri sendiri. Sehingga dapat memberi sikap professional sebagai pekerja seni dan mendapat nama baik untuk diri sendiri dan orang lain. Serta Sakadathu akan mendapat penghasilan yang memuaskan tanpa adanya pengeluaran yang tidak penting.
\end{abstract}




\section{DAFTAR ISI}

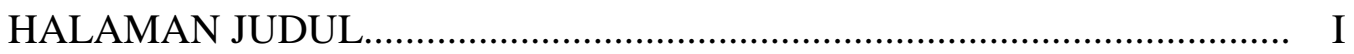

PERSETUJUAN PEMBIMBING......................................................... Ii

LEMBAR PENGESAHAN .............................................................. iii

PERNYATAAN KEASLIAN ............................................................ iv

MOTTO DAN PERSEMBAHAN................................................... V

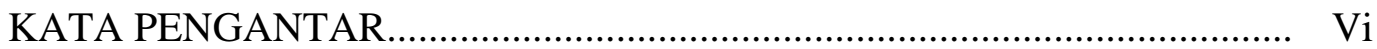

ABSTRAK

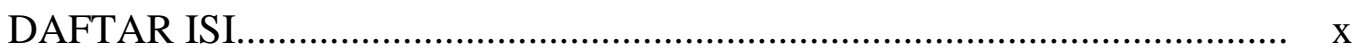

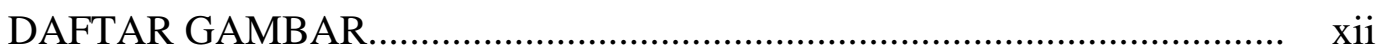

DAFTAR LAMPIRAN ........................................................................... Xii

\section{BAB 1 PENDAHULUAN}

1.1 Latar Belakang Masalah......................................................................... 1

1.2 Rumusan Masalah.............................................................................. 5

1.3 Tujuan Penelitian........................................................................... 5

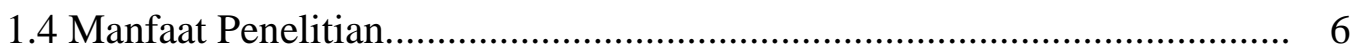

1.5 Sistematika Skripsi...................................................................... 6

BAB 2 LANDASAN TEORI 
2.1 Psikologi Umum.

8

2.2 Psikologi Musik

13

2.3 Gaya Hidup

2.4 Kajian Pustaka.

21

2.5 Kerangka Pikir.

\section{BAB 3 METODE PENELITIAN}

3.1 Pendekatan Penelitian

3.2 Sasaran Penelitian.

28

3.3 Lokasi Penelitian

28

3.4 Metode Pengumpulan Data.

28

3.5 Teknik Studi Dokumentasi

30

3.6 Studi Pustaka.

30

3.7 Teknik Analisis Data.

\section{BAB 4 HASIL PENELITIAN DAN PEMBAHASAN}

4.1 Gambaran Lokasi Penelitian.............................................. 35

4.2 Profil Sakadathu Band.................................................................. 37

4.3 Karakter Psikologis Personil Sakadathu.................................................. 39

4.4 Karakter Psikologis Personil Sakadathu Ditinjau Dari Perform Diatas Panggung. 
Dibawakan Diatas Panggung.....

4.6 Karakter Psikologis Personil Sakadathu Ditinjau Dari Tempat Kerja......

4.7 Pembahasan.

BAB 5 PENUTUP

5.1 Simpulan......................................................... 58

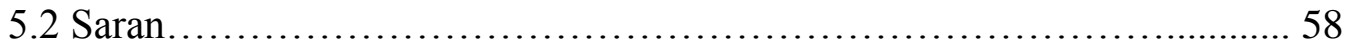

DAFTAR PUSTAKA................................................... 60

LAMPIRAN-LAMPIRAN ........................................... 63 


\section{DAFTAR GAMBAR}

Gambar 4.1 Peta Liquid Semarang................................................ 36

Gambar 4.2 Liquid Semarang.................................................... 36

Gambar 4.3 Profil Sakadathu....................................................... 39

Gambar 4.4 Girdha Vokalis................................................. 41

Gambar 4.5 Ardhi Gitarist.................................................... 43

Gambar 4.6 Vientan Keyboardist....................................... 47

Gambar 4.7 Inu Drummer................................................. 48

Gambar 4.8 perform Sakadathu Di Liquid............................... 52 


\section{DAFTAR LAMPIRAN}

1. Pedoman Observasi.............................................................. 63

2. Lembar Observasi........................................................................... 64

3. Pedoman Wawancara..............................................65

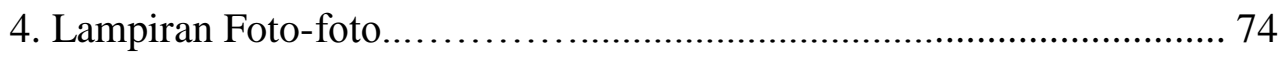

5. Surat Ijin Penelitian.................................................. 78

6. Surat Keputusan Dosen Pembimbing..................................79 


\section{BAB 1 \\ PENDAHULUAN}

\subsection{Latar Belakang}

Indonesia merupakan negara kepulauan yang terdiri dari macam budaya. Adanya fakta tersebut kebudayaan yang dimiliki pun beraneka ragam. Pengertian kebudayaan adalah hasil budi daya manusia yang tidak akan lepas dari pengaruh lingkungan tempat tinggal kelompok manusia. Manusia senantiasa melakukan segala kegiatan, baik yang berupa belajar bekerja atau kegiatan lainnya. Kebudayaan menurut Koentjoroningrat (1986: 203-204), terdiri dari tujuh unsur yang merupakan isi dari semua kebudayaan yang ada di dunia, yakni: (1) Bahasa,

(2) Sistem pengetahuan, (3) Sistem organisasi, (4) Sistem teknologi, (5) Sistem ekonomi, (6) Sistem religi, dan (7) Kesenian.

Contoh unsur kebudayaan adalah kesenian. Seni merupakan kebutuhan rohani bagi setiap individu. Seni pada dasarnya adalah rekayasa (ciptaan) manusia, namun rasa seni bukanlah hasil rekayasa. Rasa itu ada dan menjadi bagian yang tidak terpisahkan dari diri setiap manusia. Menurut Koentjoroningrat (1974: 207), kesenian dibagi menjadi dua yaitu seni rupa atau seni yang dapat dilihat dengan indra mata dan seni musik atau yang dapat dinikmati dengan indra telinga.

Bentuk kesenian salah satunya adalah seni suara, bentuk seni suara ini antara lain seni musik dan seni vokal. Seni musik sebagai salah satu cabang seni menurut Jamalus (1998:1-2), adalah suatu hasil karya yang mengungkapkan 
pikiran dan perasaan penciptanya melalui unsur-unsur musik, seperti irama, melodi, harmoni bentuk, struktur lagu dan ekspresi sebagai satu kesatuan. Berhubungan dengan pernyataan tersebut, maka dapat diartikan bermusik sebagai bagian dari perilaku berkesenian yang pada dasarnya merupakan proses menyampaikan pesan, emosi, dan nilai kemanusiaan atau hasil tafsir pribadi, atau kelompok seniman menyampaikan hasil karyanya melalui suara dalam bentuk ekspresi musikal. Sehingga dalam musik terjadi proses komunikasi antara perasaan dan pengalaman dengan orang lain yang terungkap dalam pesan musiknya.

Asal mula kata "musik" berasal dari bahasa yunani "Mousikos", "Mousikos" dilambangkan sebagai dewa keindahan bangsa yunani yang menguasai seni dan ilmu pengetahuan. Dari kata "mousike" lahir kata "musik". Menurut metologi kuno, “mousike” dimaksudkan dari kaum Muzen (Ensiklopedi Umum, 1988:16).

Musik bukan hanya sekedar nada rendah tinggi tertentu, dengan irama tertentu, keras lunak, cepat lambat, tetapi juga merupakan pengembangan pengetahuan musik ke pengetahuan tentang proses perilaku manusia yang lain dan lebih luas. Musik yang terlihat sebagai salah satu aspek lanjut dari perilaku manusia yang mengambil tempatnya disamping aktivitas manusia yang banyak.

Indonesia kaya akan ragam musik, baik musik tradisional seperti : karawitan/gamelan, rebana, gambang kromong dan lain-lain, maupun musik non tradisional seperti : jazz, rock, pop, R\&B, Top 40 dan lain-lain. Dari keragaman musik tersebut yang menjadi minat atau ketertarikan pengunjung di Liquid 
Semarang adalah musik R\&Bkarena musik ini termasuk dalam musik malam, gabungan dari musik tekno dan Band bisa juga dikolaborasi dengan musik DJ. Hal ini dapat dibuktikan dan disaksikan dengan tumpah ruahnya pengunjung yang menikmati musik R\&B yang di selenggarakan di LiquidSemarang setiap Sabtu malam.Group musik yang menyajikan musik R\&B di Liquid Semarang adalah "Sakadathu”.Bukti lain bahwa musik R\&Bbanyak mendapat tempat di hati masyarakat, yaitu dengan meluasnya pertunjukan-pertunjukan musik R\&B yang mampu merambah tempat-tempat yang berkesan elit seperti di hotel-hotel berbintang, gedung-gedung, restoran, stasiun televisi, yang mulanya menyuguhkan musik rock, pop, jazz, kini dapat dinikmati pula musik-musik R\&Byang dimainkan di sana.

Tanggapan Masyarakat pada musik R\&B yang dimainkan Sakadathu nampaknya ditanggapi secara positif. Hal ini terlihat dengan beberapa pengunjung di setiap minggunya yang menyaksikan musik $R \& B$, dan ada pula pengunjung yang mengekspresikan dengan ikut bernyanyi bersama, dan ada juga yang berjoget bersama.

Group musik Sakadathu pada awalnya hanya sebagai pemian musik di tempat-tempat wisata seperti tempat wisata Bandungan. Namun, dari banyaknya pemain musik, hanya group Sakadathu yang membawakan jenis musik R\&B dan mengaransemen lagunya dengan menggunakan vokal Trio (suara 1,2,3) serta penyajiannya mengunakan alat musik band seperti gitar, bass, drum, keyboard, tekno atau alat musik DJ. Dari perjalanannya menjadi pemain musik R\&B pada akhirnya bertemu dengan pemilik club malam yaitu Liquid yang sedang berwisata 
di Bandungan. Pemilik club Liquid merasa tertarik dengan aransemen lagu yang dibawakan oleh group musik Sakadathu dan mengajak kerjasama untuk bermain di Liquid.

Dari beberapa restoran atau kafe yang ada di kota Semarang, hanya Liquid yang menyuguhkan musik R\&B setiap sabtu malam, selalu didatangi penonton setiap minggunya untuk menyaksikan pertunjukan tersebut. Di Liquid tidak menyuguhkan group lain selain group Sakadathu yang tampil pada Sabtu malam karena group Sakadathu sudah menjadi home band Liquid yang sudah dikontrak. Mengenai jenis musik lain, tidak dimainkan di club malam Liquid kecuali musik DJ akan tetapi tidak menutup kemungkinan ketika group Sakadathu tampil memainkan lagu yang lain bila ada permintaan.

Sekarang Sakadathu sudah 1 tahun menjadi home band di Liquid Semarang. Banyak terjadi fenomena-fenomena yang sering terjadi dan mereka rasakan, seperti, penonton yang sering membuat kerusuhan saat Sakadathu bermain, penonton yang sering berlaku tidak sopan terhadap salah satu vokalis band Sakadathu, dikarenakan penonton yang tidak dapat mengontrol diri saat terkena pengaruh alkohol. Disisi lain, ternyata terdapat dampak negatif yang mempengaruhi para pemain band Sakadathu di lingkungan tersebut. Sebagai contoh, gaya hidup mereka secara tidak langsung mengikuti alur dari lingkungan tersebut.

Dengan bergaul dengan lingkungan dunia malam secara paksa atau tidak dipaksa mereka merasa harus melakukan hal negatif (minuman beralkohol, narkoba, dll) tersebut karena hanya untuk menghormati para penonton kalangan 
atas di Liquid Semarang. Hal yang sering terjadi seperti ini, berakhir menjadi kebiasaan untuk salah satu pemain band Sakadathu.

\subsection{Rumusan Masalah}

Berdasarkan paparan di atas permasalahan yang hendak diteliti dalam penelitian ini adalah sebagai berikut:

Bagaimanakah psikologi para pemain band Sakadathu dalam musik dunia malam Liquid Semarang dilihat dari gaya hidup dan gaya bermusiknya ?

\subsection{Tujuan Penelitian}

Tujuan penelitian yang ingin dicapai dalam penelitian ini untuk mengetahui psikologi para pemain band Sakadathu dalam musik club malam Liquid Semarang.

\subsection{Manfaat penelitian}

\subsubsection{Manfaat Teoritis}

a. Dapat digunakan sebagai referensi ilmiah bagi masyarakat umum khususnya sendratasik untuk penelitian-penelitian ilmiah berikutnya.

b. Bagi pengamat seni, penelitian ini dapat memberikan informasi mengenai pengaruh psikologi para pemain musik club malam di Semarang. 


\subsubsection{Manfaat Praktis}

a. Dapat memberikan informasi kepada masyarakat umum tentang bagaimana Kajian psikologi para pemain band Sakadhatu dalam musik club malam liquid.

b. Bagi mahasiswa Sendratasik dapat digunakan sebagai wacana untuk menambah pengetahuan tentang pengaruh psikologi para pemain musik club malam di Semarang.

\subsection{Sistematika Skripsi}

Sistematika skripsi ini terdiri dari 3 bagian besar yaitu :

1.5.1 Bagian awal: Halaman judul, halaman pengesahan, halaman motto dan persembahan, kata pengantar, sari dan daftar isi.

\subsubsection{Bagian isi skripsi ini tediri dari :}

BAB I : Pendahuluan, yang berisi tentang :

I. Judul Penelitian

II. latar belakang masalah

III. permasalahan

IV. tujuan penelitian

V. manfaat penelitian

VI. sistematika skripsi

BAB II : Landasan Teori

Landasan Teori meliputi psikologi umum, psikologi musik, gaya hidup, profil Sakadhatu, fungsi. 
BAB III : Metodologi Penelitian

Bab ini berisi metode-metode yang dipakai dalam melaksanakan penelitian, meliputi cara penentuan dan pengambilan data serta analisis data.

BAB IV : Berisi hasil penelitian dan pembahasan penelitian, yang meliputi Gambaran Umum club malam Liquid, kajian psikologi para pemain band Sakadathu dalam musik club malam liquid Semarang.

BAB V : Penutup, berisi tentang simpulan dan saran

1.5.3 Bagian Akhir : Daftar Pustaka, Lampiran-lampiran. 


\section{BAB 2}

\section{LANDASAN TEORI}

\subsection{Psikologi Umum}

Manusia pada hakekatnya tidak dapat dipisahkan dari lingkungan masyarakatnya.Menurut Sarwono (1984: 1) bahwa seseorang telah memiliki minat yang besar terhadap tingkah laku dalam lingkungan sosialnya. Hal itu dipengaruhi oleh sebagian faktor, bahwa manusia pada dasarnya membutuhkan sesuatu untuk memenuhi kebutuhan hidupnya. Untuk melanjutkan psikologi yang dialami dalam diri manusia, maka disusunlah beberapa definisi dan beberapa pendapat mengenai psikologi sebagai berikut:

\subsubsection{Psikologi Sosial}

Menurut Sarwono (1984: 3), ruang lingkup psikologi sosial memiliki beberapa definisi, diantaranya sebagai berikut: (1) Studi Pengaruh Sosial Terhadap Proses Individual, (2) Studi tentang Individual bersama, (3) Studi Tentang Interaksi Kelompok.

Studi Pengaruh Sosial Terhadap Proses Individual, yang dimaksud dengan penelitian ini yaitu untuk mengetahui proses seseorang berdasarkan pengaruh sosial yang sedang dihadapinya. Contoh pernyataan tersebut dapat diketahui melalui studi tentang persepsi, mengenai sebuah anggapan individual itu sendiri. Misalnya seseorang memutuskan untuk menjadi musisi tanpa adanya paksaan atau dorongan dari orang lain. 
Definisi psikologi sosial selanjutnya yaitu studi tentang individual bersama.Pada umumnya sifat dari psikologi ini didasari dengan kesamaan sikap sosial.Sikap sosial yang dimaksud adalah penggabungan persepsi dari kedua individu tersebut untuk mencapai tujuan bersama.Contoh pernyataan tersebut dapat diketahui melalui studi tentang proses-proses penggabungan individual bersama. Misalnya sesorang tersebut memutuskan untuk menjalin kerjasama kepada pihak lain dalam pembuatan suatu barang produksi seperti produksi gitar.

Contoh yang terakhir mengenai adanya studi interaksi kelompok yaitu, Interaksi kelompok dapat diartikan sebagai pemberi jalan untuk tujuan yang sama dalam menjalin sebuah kerja sama yang dapat memberikan keselarasan dalam komunikasi. Hal yang dapat dilihat dalam kehidupan sehari-hari salah satunya: (1) kerjasama antara sebuah komunitas dengan komunitas lain dan (2) bentuk peran sosial yang berupa kerjasama antar lembaga dalam membantu korban bencana

Berdasarkan pengertian definisi psikologi sosial diatas dapat disimpulkan bahwa psikologi sosial mempunyai keterkaitan dengan kehidupan individual sehari-hari.Hal itu dikarenakan pada dasarnya setiap individu membutuhkan interaksi untuk mencapai tujuan hidup.Psikologi sosial juga sebagai sebuah ilmu pengetahuan yang mempelajari tingkah laku individu sebagai fungsi dari rangsangan sosial (Sarwono, 1984: 4).

Psikologi sosial bertujuan untuk mengerti suatu gejala atau fenomena. Dengan mengerti suatu fenomena, kita dapat membuat peramalan-peramalan tentang kapan akan terjadinya fenomena tersebut dan bagaimana dia akan terjadi. Dengan pengertian dan kemampuan peramalan itu, kita dapat mengendalikan 
fenomena itu sampai batas-batas tertentu. Terkadang tidak selalu kita bisa mengontrol suatu gejala atau fenemona itu, sebagai contohnya seorang pengemudi mobil dapat mengendalikan mobilnya tanpa dia mengerti betul tentang mekanisme yang menggerakkan mobil tersebut.

Dalam psikologi sosial memerlukan teori, dan menyusun teori diperlukan data atau fakta dari pengalaman.Tetapi tidak semua data dapat digunakan untuk menyusun teori, melainkan hanya yang memenuhi syarat.Syarat utama adalah data tersebut diperoleh dari suatu pengamatan dalam suatu situasi dimana faktorfaktor yang berpengaruh. Faktor-faktor yang berpengaruh, diantaranya sebagai berikut:

\section{a. Konsep Diri}

Menurut Ghufron (2010: 13), bahwa konsep diri adalah apa yang dirasakan dan dipikirkan oleh seseorang mengenai dirinya sendiri. Pengetahuan individu tentang dirinya mencakup pengetahuan "siapa saya" yang memberikan gambaran tentang diri saya, dan gambaran ini dinamakan citra diri. Citra diri dengan ini dapat diartikan sebagai: (1) kesan diri sendiri secara keseluruhan yang mencakup pendapat terhadap diri sendiri, (2) Pendapat tentang gambaran diri dihadapan orang lain dan (3) Pendapat tentang hal-hal yang akan dicapai. Berdasarkan penjelasan diatas, kesimpulan dari pengertian konsep diri adalah apa yang dirasakan dan dipikirkan oleh seseorang mengenai dirinya sendiri. Konsep diri juga tidak berkembang dengan sendirinya, tetapi berkembang dengan adanya interaksi dengan individu yang lain khususnya dengan lingkungan sosial. 
Menurut Acocella dalam Gufron (2010: 17), aspek aspek dalam konsep diri meliputi: (1) Pengetahuan, yaitu segala sesuatu yang diketahui tentang dirinya tersebut. Individu dalam benaknya terdapat sebuah daftar yang menggambarkan dirinya, kelengkapan atau kekurangan fisik, usia, jenis kelamin dan sejenisnya. (2) Harapan, seseorang pada masa tertentu akan mempunyai suatu aspek akan pandangan tentang dirinya. Individu juga memiliki aspek tentang kemungkinan dirinya menjadi apa dimasa mendatang. (3) Penilaian, dalam suatu penilaian, seorang individu berkedudukan sebagai penilai tentang dirinya sendiri. Fakta penilaian jika tidak sesuai dengan harapan dan standar diri, maka akan semakin rendah harga diri seseorang.

\section{b. Kontrol Diri}

Faktor berikutnya yang mempengaruhi yaitu kontrol diri. Menurut Ghufron (2010: 21), kontrol diri diartikan sebagai kemampuan untuk menyusun, membimbing, mengatur, dan mengarahkan bentuk perilaku yang dapat membawa ke arah konsekuensi positif. Kontrol diri merupakan salah satu potensi yang dapat dikembangkan dan digunakan individu dalam menghadapi kondisi yang terdapat dalam lingkungan sekitar.Dalam kontrol diri dibutuhkan kepercayaan diri, karena kepercayaan diri adalah salah satu aspek yang penting pada seseorang. Tanpa adanya kepercayaan diri akan banyak menimbulkan masalah pada diri seseorang. Kepercayaan diri merupakan aspek paling berharga pada diri seseorang dalam kehidupan bermasyarakat, karena dengan kepercayan diri, seseorang mampu mengaktualisasikan segala potensi dirinya. 


\section{c. Penyesuaian Diri}

Faktor terakhir yang mempengaruhi yaitu penyesuaian diri. Manusia dalam kehidupan sehari-hari tidak akan pernah terbebas dari berbagai perasaan yang tidak menyenangkan. Definisi penyesuaian diri adalah salah satu aspek penting dalam usaha manusia untuk menguasai perasaan yang tidak menyenangkan atau tekanan akibat dorongan kebutuhan, usaha memelihara keseimbangan antara pemenuhan kebutuhan dan tuntutan lingkungan, dan usaha menyelaraskan hubungan individu dengan realitas (Ghufron, 2010: 49).

Menurut Scheineder dalam Gufron (1964: 52), macam-macam penyesuaian diri terdiri dari: (1) Penyesuaian diri personal, penyesuaian yang diarahkan kepada diri sendiri yang meliputi penyesuaian diri fisik dan emosi, penyesuaian diri seksual dan penyesuaian diri moral. (2) Penyesuaian diri sosial, merupakan aspek khusus dari kelompok sosial dan melibatkan langsung dengan pola dan hubungan diantara kelompok tersebut dan saling berhubungan secara integral, sebagai contoh penyesuaian diri di rumah, sekolah dan masyarakat.

Faktor yang mempengaruhi penyesuaian diri diantaranya adalah kepribadian yang dipengaruhi oleh fakta internal dan fakta eksternal individu dari interaksi tersebut. Dengan interaksi yang harmonis diharapkan terjadinya perkembangan kepribadian yang sehat, sebaliknya jika tidak harmonis diduga akan muncul masalah perilaku. Dalam garis besar, fakor yang mempengaruhi individu dibagi atas: (1) Internal, faktor kondisi jasmani, psikologis, kebutuhan, mental dan motivasi, (2) Eksternal, faktor yang berasal dari lingkungan rumah, keluarga, sekolah dan masyarakat. 


\subsection{Psikologi Musik}

Awal munculnya psikologi musik diawali dengan pembahasan mengenai psikologi musik dimulai dengan interdisiplin antara kognisi dan musik. Menurut Djohan (2003: 21), dimulai sejak Abad 17 dan seterusnya dunia sains telah terbentuk sedemikian rupa, begitu dengan ilmuwan-ilmuwannya yang terdiri dari filsuf, musisi, matematikawan, dan ahli psikologi. Mereka tertarik menyelidiki sifat dasar perilaku manusia yang lebih banyak dimotivasi oleh sifat manusia melalui argumen-argumen logis atau eksperimen empirik tidak lagi hanya mendasarkan pada pengertian dan kebenaran ontologis yang bersumber dari ajaran agama. Proses penyelidikan yang dilakukan seorang ahli terhadap individu disertai munculnya uji coba pada sebuah objek.

Dampak kecenderungan ini berakibat menjauhnya pandangan keilmuan dari hirarki pengetahuan kuno yang dirasa sudah kurang dapat dipercaya.Disini awal mula kekuatan sains menggantikan kekuatan kepercayaan agama.Menurut John Locke dalam Djohan (2003: 22), keadilan bukan intuisi atau kepercayaan agama semata.argumentasi merupakan salah satu tipe pengetahuan yang didasarkan pada intuisi, seperti pengetahuan tentang keberadaan seseorang, diri sendiri, dan sensasi.

Pada dasarnya elemen-elemen keadilan justru diperoleh dari penyelidikan dan penelitian yang rasional. Sebaliknya pengetahuan dalam dunia fisik hanya dapat diperoleh melalu hasil pemikiran dari beberapa ahli.Dalam hal ini musik menjadi penting dikarenakan memiliki peran pokok.Menurut Plato dalam Djohan 
(2003: 22), bahwa ada hubungan ontologis antara logika dan suara musik dengan sifat asli seluruh alam semesta ini.

Alasan yang melanjutkan ketertarikan dari penelitian tersebut adalah kepercayaan kuno yang mengatakan suara musik tidak hanya berisi rahasia alam semesta tetapi dalam ketepatan matematis, ketepatan emosi, dan karakter manusia. Pada awal Abad 15 dan 16 menemukan terjemahan baru dari budaya Yunani kuno dan Roma yang mengatakan bahwa beberapa motif melodi tertentu adalah matematis dan phytagorian. Penemuan Plato ini dikutip para komponis dan musisi Abad 18 yang menerapkan rasio yang berasal dari bilangan 1, 2, dan 3 menghasilkan suara yang sempurna bagi manusia.

Melalui penemuan-penemuan ini terdapat mata rantai yang saling berkesinambungan antara semua ikhtiar yang dilakukan manusia. Menurut Immanuel Kant dalam Djohan (2003: 23), semua aspek perilaku manusia mendorong timbulnya seni, dan itu sama dengan sains.

Seni pada dasarnya memiliki hubungan dengan aspek perilaku manusia.Manusia memiliki rasa ingin tahu yang cenderung untuk melakukan sebuah penelitian dan penemuan untuk mendapat bukti yang benar. Dengan adanya penemuan - penemuan tersebut, manusia dapat mengembangkan secara luas bagaimana hubungan antara psikologi dengan musik. Seperti dalam contoh , penemuan dari para ahli matematis yang mengaitkan bilangan 123 dapat menghasilkan suara sempurna manusia. 


\subsection{Hubungan Antara Psikologi dan Musik}

Menurut Parker dalam Djohan (2003: 24), musik adalah produk pikiran. Maka elemen (fisika dan kosmos) dalam bentuk frekuensi, amplitude dan durasi belum menjadi musik bagi manusia sampai semua itu ditransformasikan secara neurologis dan diinterpretasikan melalui otak menjadi pitch (nada-harmoni), timbre (warna suara), dinamika (keras-lembut), dan tempo (cepatlambat).Trensformasi ke dalam musik dan respon manusia (perilaku) adalah unik untuk dikenali (kognisif) karena otak besar manusia berkembang dengan sangat pesat sebagai akibat dari pengalaman musikal sebelumnya.

Psikologi sebagai ilmu tentang pikiran dan perilaku akan menjadi suatu pengetahuan dasar yang dibutuhkan untuk mengetahui bagaimana persisnya kinerja sensori menghasilkan peningkatan perkembangan otak serta memperkaya hidup manusia sementara pengetahuan kognisif berkewajiban memastikan hubungan semua jaringan saraf sensori (indera), motorik, koneksi antar saraf, dan saraf otak layaknya sebuah computer raksasa. Di dalamnya termasuk pembahasan aspek belajar yang meliputi pemahaman dan efisiensi komunikasi dari fungsi saraf.

Individu yang berperan dalam pengelolaan psikolog musik harus bertanggung jawab dan berinisiatif pada pekerjaan yang terintegral. Peran tersebut sebagai contoh adalah seorang psikolog musik dalam ruang lingkup interdisiplin bahkan multidisiplin dalam upaya menemukan jawaban atas pertanyaan tentang pengaruh dan respon. Untuk itu dibutuhkan penggabungan seni dan pengetahuan musik, mengasimilasi dan memberikan informasi kesatuan tersebut serta 
bertanggung jawab untuk diseminasi hasil penggabungan itu ke dalam praktik pendidikan, kurikulum dan pratik klinis, penelitian dan model-model teoritis lainnya.

\subsection{Musik sebagai Perilaku Manusia}

Menurut Blacking dalam Djohan (2003: 27), musik adalah perilaku sosial yang kompleks dan universal. Setiap masyarakat memiliki apa yang disebut dengan musik dan setiap anggota masyarakatnya adalah musikal. Dalam kehidupan sehari-hari kita dapat melihat jelas antara siapa yang "memproduksi" musik dan siapa yang mayoritas mengkonsumsi musik. Golongan mayoritas yang "mengkonsumsi” musik, mereka akan mendengarkan, menirukan, dan berupaya untuk mengembangkan. Dalam masyarakat terdapat pula individu yang cenderung diam atau pasif terhadap musik yang dikarenakan beberapa faktor.Pada dasarnya dalam situasi ini mereka juga terkesan sedang memahami musik.Situasi ini yang dapat disebut musik sebagai perilaku manusia begitu juga sebaliknya.

Menurut Miller dalam Djohan (2003: 29), bahwa perilaku musik yang rumit dalm sebuah pertunjukan musik adalah wujud dari kapasitas yang diwariskan sejak nenek moyang untuk menunjukkan suatu perilaku dengan maksud menarik pasangannya. Dalam interaksi antar manusia terjadi proses saling meningkatkan pemahaman sebagai suatu budaya yang memainkan peran signifikan dalam mematangkan persepsi dan kognisi. Perkembangan perilaku musik dalam kenyataannya semakin kuat dipengaruhi oleh proses evolusi dalam pikiran. 


\subsection{Perkembangan Perilaku Musikal}

Dalam interaksi antar manusia terjadi proses saling meningkatkan pemahaman sebagai suatu budaya dalam mematangkan persepsi. Perkembangan perilaku musik dalam kenyataannya semakin kuat dipengaruhi oleh proses evolusi dalam pikiran. Menurut Spelke dalam Djohan (2003: 29), anak-anak lebih cepat mengembangkan kompetensi musik sebagai proses hasil belajar dengan lingkungan. Menurut Trehub dalam Djohan (2003: 30), Bayi berusia 6 bulan telah mampu menjadi pendengar.

Mereka merespon terhadap bentuk melodi yang konstan, walaupun melodi serta pola naik turun dengan perubahan pada pitch.Perilaku musikal tersebut tidak hanya berupa mendengarkan suara tetapi memproduksi dan merespon secara aktif.Memahami kecenderungan musikalitas yang dimiliki manusia pada bayi daripada ekspresi musikal yang ditunjukkan oleh orang dewasa yang dalam budaya tertentu dianggap sebagai produk dari evolusi.Kecenderungan untuk menjadi musikal tidak lebih dari sekedar menjadi pendengar yang kompeten.

Secara spesifik musik dirangkai untuk mengeksplorasi sebuah interaksi sosial.Setiap anak terlibat dalam aktifitas musikal dapat memberikan media interaksi sosial, ruang bebas untuk mengeksplorasi perilaku sosial untuk mengetahui potensi anak melalui aksi anak tersebut.Pada dasarnya musik dapat merubah situasi yang dapat membantu perkembangan kapasitas kognitif anak.Musik pada bayi dan anak berbeda dengan orang dewasa dalam setiap budaya.Orang dewasa memiliki kebutuhan musik sendiri yang berbeda dengan bayi dan anak. 
Dengan adanya pendapat orang dewasa yang dirasa memiliki pemikiran bahwa musik dapat dijadikan sebagai suatu kebutuhan, berdampak pula dengan adanya tindakan lebih untuk mengembangkan salah satu fungsi musik tersebut. Menurut Cook dalam Djohan (2003: 35), ketika kita berbicara mengenai kombinasi pitch atau interval sebenarnya kita tidak berbicara mengenai realitas psikoakustik, tetapi kita meniru pengalaman musik melalui terminologi kategori musikologi yang diwujudkan dalam latihan pendengaran. Hal itu dapat diperjelas dengan sebuah kesimpulan bahwa hal mendasar mengenai musik dapat berkembang menurut motivasi masing masing individu dengan cara melakukan hal yang paling dasar dalam bidang musik.

\subsection{Gaya Hidup}

Di tengah perkembangan masyarakat modern menuju post modern, selain ditandai dengan munculnya masyarakat informasi dan masyarakat konsumsi, juga ditandai oleh perkembangan gaya hidup masyarakat yang lebih banyak dikendalikan oleh kekuatan industri budaya. Di era masyarakat modern, gaya hidup mempengaruhi seseorang membangun identitas di hadapan lingkungan sosialnya.

Menurut Piliang dalam Bagong (2006: 81), beberapa sifat umum dari gaya hidup, antara lain: (1) gaya hidup sebagai sebuah pola yaitu sesuatu yang dilakukan atau tampil secara berulang-ulang; (2) yang mempunyai massa atau pengikut sehingga tidak ada gaya hidup yang sifatnya personal; dan (3) mempunyai daur hidup, artinya ada masa kelahiran, tumbuh, puncak, surut, dan 
mati. Gaya hidup oleh berbagai ahli sering disebut ciri sebuah dunia modern dan modernitas. Artinya, siapa yang hidup dalam masyarakat modern akan menggunakan gagasan tentang gaya hidup untuk menggambarkan tindakan sendiri maupun orang lain.

Menurut Chaney dalam Bagong (2013: 40), Gaya hidup adalah pola-pola tindakan yang membedakan satu orang dengan yang lain. Gaya hidup selalu berkaitan dengan upaya untuk membuat diri eksis dalam cara tertentu dan berbeda dari kelompok lain.

Gaya hidup tumbuh bersamaan dengan globalisasi, perkembangan pasar bebas, dan tranformasi kapitalisme konsumsi. Melalui dukungan iklan, budaya popular, media massa, dan tranformasi nilai modern yang dilakukan, kapitalisme konsumsi akan memoles gaya hidup dan membentuk masyarakat konsumen.

Gaya hidup merupakan cara-cara terpola dalam menginvestasikan aspekaspek tertenti kehidupam sehari-hari dengan nilai sosial atau simbolis, sekaligus merupakan cara bermain dengan identitas. Dengan menampilkan gaya hidup yang dipilih, seseorang bukan hanya untuk memenuhi hasrat dan kebutuhan dirinya sendiri, tetapi sekaligus juga sebagai cara untuk memperlihatkan atau meneguhkan dari kelompok sosial mana mereka berada. 


\subsection{Kajian Pustaka}

Penelitian yang dilakukan oleh Agus Untung Yulianta (2011) yang berjudul "KAJIAN PSIKOLOGI MUSIK DALAM MEMBANGUN PENDIDIKAN KARAKTER BANGSA.” menghasilkan suatu kesimpulan bahwa Kajian psikologi musik dalam membangun pendidikan karakter bangsa perlu rumusan tentang nilai-nilai yang dikembangkan ke dalam pilar-pilar kependidikan seni budaya dan karakter bangsa : (1) Agama: masyarakat Indonesia adalah masyarakat beragama. Oleh karena itu, kehidupan individu, masyarakat, dan bangsa selalu didasari pada ajaran agama dan kepercayaannya. Secara politis, kehidupan kenegaraan pun didasari pada nilai-nilai yang berasal dari agama. Atas dasar pertimbangan itu, maka ilmu kejiwaan musik harus berakar pada nilai-nilai pendidikan budaya sebagai muatan lokal dan pendidikan karakter bangsa harus didasarkan pada nilai-nilai dan kaidah yang berasal dari agama. (2) Pancasila: negara kesatuan Republik Indonesia ditegakkan atas prinsip-prinsip kehidupan kebangsaan dan kenegaraan yang disebut Pancasila. Pancasila terdapat pada Pembukaan UUD 1945 dan dijabarkan lebih lanjut dalam pasal-pasal. Artinya, nilai-nilai yang terkandung dalam Pancasila menjadi pilar yang mengatur kehidupan politik, hukum, ekonomi, kemasyarakatan, seni dan budaya. Dalam meningkatkan pendidikan karakter bangsa yang ber Bhineka Tunggal Ika,yakni bertujuan mempersiapkan bangsa yang lebih baik, yaitu warga negara yang memiliki kemampuan, kemauan, dan menerapkan nilai- nilai Pancasila dalam kehidupannya. (3) Budaya: sebagai suatu kebenaran bahwa tidak ada manusia yang hidup bermasyarakat yang tidak didasari oleh nilai-nilai budaya yang diakui 
masyarakatnya. Nilai-nilai 13 seni dan budaya itu dijadikan dasar dalam pemberian makna terhadap suatu konsep dan arti komunikasi antar anggota masyarakat. Posisi budaya yang demikian penting dalam kehidupan masyarakat mengharuskan seni dan budaya menjadi sumber nilai dalam pendidikan budaya dan karakter bangsa. (4) Tujuan Pendidikan Nasional: sebagai rumusan kualitas yang harus dimiliki setiap warga negara Indonesia, dikembangkan oleh berbagai satuan pendidikan di berbagai jenjang dan jalur. Tujuan pendidikan nasional memuat berbagai nilai kemanusiaan yang harus dimiliki warga Negara dan merupakan sumber operasional dalam pengembangan pendidikan seni budaya dan karakter bangsa.

Penelitian lainnya dilakukan oleh ULFA AMALIA(2008) yang berjudul “KONSEP DIRI REMAJA PUNK” menghasilkan kesimpulan Konsep diri remaja punk dipengaruhi dari dalam maupun lingkungan luar dirinya, dalam hal ini ada empat aspek diantaranya yaitu pertama, aspek fisik dimana remaja punk merasa bangga dan percaya diri dengan dandanan gaya Mohawk punk, merasa lebih menjiwai punk dengan memakai tindik ditubuhnya, sehingga hal ini mereka terlihat selalu ingin menonjol dengan penampilannya. kedua, aspek sosial dimana orang tua maupun masyarakat memberikan pandangan negatif pada anak punk dan merekapun menunjukkan sikap tidak perduli (cuek). Selain itu juga kondisi ekonomi remaja punk yang menengah kebawah membuat dirinya merasa harus mandiri dengan cara apapun termasuk ngamen ataupun nyantop dan mereka semakin solid karena merasa memiliki kesamaan nasib. Perilaku negatif yang dilakukan remaja punk merupakan perilaku imitatif (meniru) dari lingkungan 
sosialnya. Ketiga, aspek moral yang berarti bahwa kebebasan dan kebersamaan yang dianut diartikan dalam hal-hal negatif, seperti minum-minum, merokok dan seterusnya. Kemudian rendahnya tingkat religiusitas, sehingga membuat remaja inipun tidak mempunyai benteng diri agar terhindar dari godaan negatif. Keempat, aspek psikis dimana remaja punk ada yang berasal dari keluarga broken home, dan dirinya tidak siap menerima perubahan yang terjadi dalam keluarganya dan memilih untuk keluar. Selain itu juga munculnya keinginan untuk mendapatkan kebebasan dan ada rasa ketidaknyamanan dengan kondisi dirumah karena sikap dan perlakuan keluarga, sehingga anak mencari kondisi yang nyaman diluar. Beberapa hal ini juga yang melatar belakangi remaja ini merasa lebih nyaman dan menjadi seorang punkers. Pada penelitian ini diperoleh juga dampak yang dialami remaja punk, yaitu adanya konflik dengan keluarga, sering bolos sekolah, menurunnya nilai sekolah, dan sering pulang malam. Namun dari berbagai hal yang dialami remaja punk ini, ada beberapa nilai-nilai positif yang mereka miliki, tetapi terabaikan karena sering sekali hanya dipandang ataupun dinilai sisi perilaku negatif yang mereka tunjukkan, diantaranya yaitu Pertama, mereka memiliki keberanian, dimana remaja punk ini berani untuk memilih hidup dijalan, menghadapi semua tantangn hidup dijalanan yang sangat keras, karena tidak semua orang memiliki keberanian yang dimiliki remaja punk ini. Kedua, Percaya diri yang tinggi, Gaya dandanan punk yang khas membuat mereka semakin percaya diri, dengan punk remaja ini tidak malu untuk tampil atau menunjukkan apa adanya diri mereka didepan umum. Ketiga, Selalu menjaga kebersamaan sesama punk, mereka selalu menjaga rasa kebersamaan diantara mereka dan 
menghindari konflik. Keempat, Solidaritas, mereka selalu membantu teman mereka yang mengalami kesusahan dan rela memeberikan apa yang mereka miliki. Kelima, Kemandirian, dimana mereka selalu ingin mendapatkan sesuatu yang diinginkannya dari hasil kerja keras mereka sendiri dan tidak merepotkan orang lain. Selanjutnya penelitian lainnya dilakukan oleh Muhammad Mu'adz (2014) dengan judul "Perkembangan Psikososial Dalam Agresivitas Remaja Angota Geng Sekolah Menengah Atas Di Yogyakarta” yang menyimpulkan pendidikan yang keras dilakukakan terus-menerus oleh orang tua.

\subsection{Kerangka Pikir}

Psikologi sosial mempunyai keterkaitan dengan kehidupan individual sehari-hari. Hal itu dikarenakan pada dasarnya individu membutuhkan interaksi untuk mencapai tujuan. Terdapat faktor yang mempengaruhi dalam psikologi sosial yaitu gaya hidup dari individual masing-masing. Setiap individu mempunyai gaya hidup masing-masing dilihat dari lingkungan sekitarnya. Dalam kehidupan dunia malam, sangat dapat berpengaruh dalam kehidupan sehari-hari, hedonis merupakan salah satunya.

Lingkungan dalam club malam sangat mempengaruhi individu menjadi hedonis. Club malam salah satunya merupakan tempat yang mudah untuk terciptanya interaksi antar individu masing-masing, mulai dari kalangan atas maupun bawah. Tergantung dalam setiap individu untuk memilih berinteraksi di lingkungan kelas atas maupun bawah. Club Malam identik dengan musik keras, 
dentuman speaker yang membuat adrenalin terpacu, dan efek dari minuman beralkohol.

Sehingga terkadang individu tidak dapat mengontrol diri pada saat berada di Club malam. Dilihat dari psikologi, musik mempunyai peranan yang penting. Musik merupakan produk pikiran, diinterpretasikan melalui otak menjadi pitch (nada-harmoni), timbre (warna suara), dinamika (keras-lembut), dan tempo (cepat-lambat). Para pemain band Sakadathu merupakan individu yang sering berinteraksi di club malam. Untuk mengetahui psikologi para pemain band Sakadathu dapat kita lihat dari gaya hidup dan gaya bermusiknya.

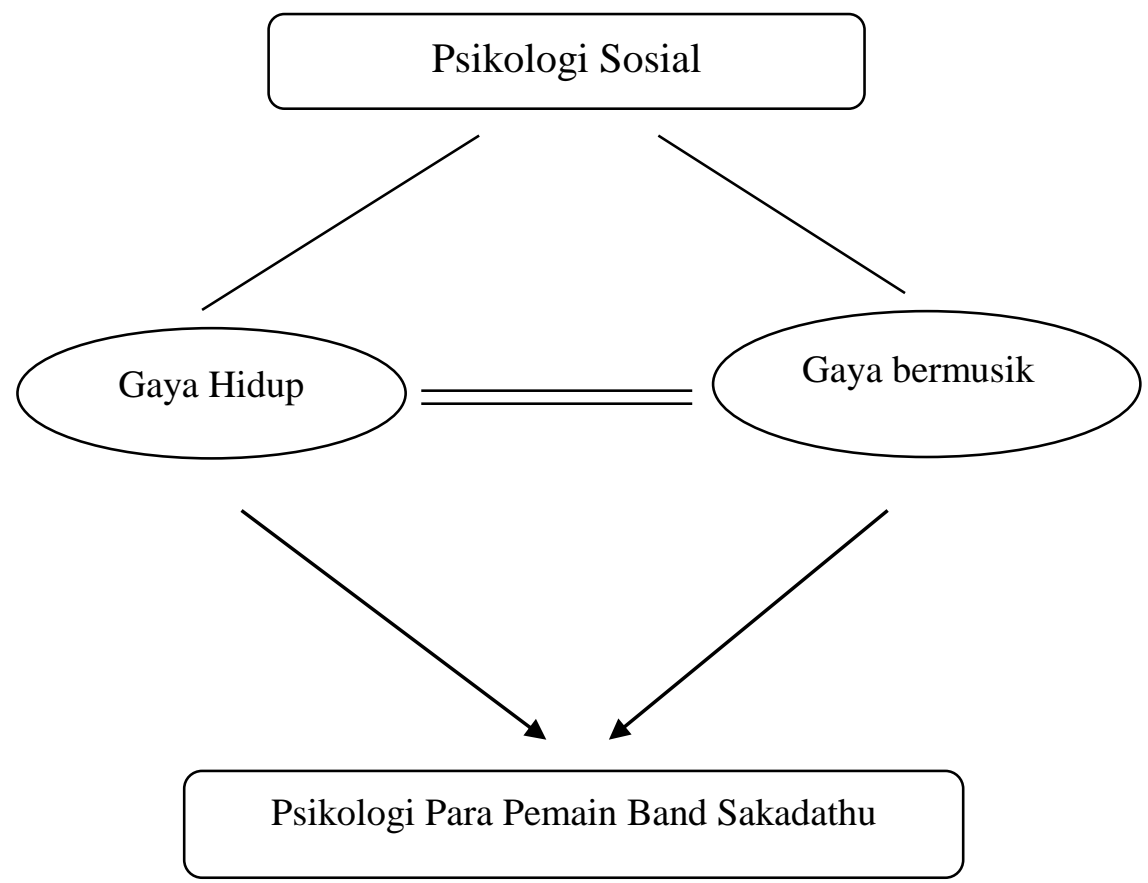

Bagan 1. Kerangka Pikir Psikologi Para Pemain Band Sakadathu (Sumber : Adhadiantin, 2015) 


\section{BAB III \\ METODE PENELITIAN}

\subsection{Pendekatan Penelitian}

Metode penelitian adalah sesuatu alat atau cara untuk melakukan pemeriksaan yang diteliti. Penyelidikan atau kegiatan pengumpulan data, pengolahan data yang dilakukan secara sistematis dan obyektif untuk memecahkan masalah persoalan praktik (Kamus Bahasa Indonesia, 1994: 1028). Dengan demikian penulis suatu penelitian harus dapat menghasilkan kajian yang bersifat obyektif, sistematis dan logis.

Metodologi merupakan syarat mutlak yang harus dipenuhi dalam suatu penelitian, karena berbobot atau tidaknya suatu penelitian sangat tergantung pada penggunaan metode penelitiannya. Metodologi penelitian adalah sekumpulan peraturan, kegiatan, dan prosedur yang digunakan oleh pelaku suatu disiplin ilmu. Metodologi juga merupakan analisis teoritis mengenai suatu cara atau metode.

Dalam penelitian ini, penulis berusaha untuk menerapkan suatu metodologi penelitian kualitatif yang mencakup pendekatan penelitian, lokasi dan sasaran penelitian, teknik pengumpulan data, teknik anak analisis data.

Metode berasal dari Bahasa Yunani "Methodos" yang berarti cara atau jalan yang ditempuh. Sehubungan dengan upaya ilmiah, maka metode menyangkut masalah cara kerja untuk dapat memahami objek yang menjadi sasaran ilmu yang bersangkutan. Fungsi metode berarti sebagai alat untuk mencapai tujuan. Adapun pengertian dan definisi metode menurut para ahli antara lain Menurut 
Rothwell \& Kazanas (dalam Nasir,1983: 5) Metode adalah cara, pendekatan, atau proses untuk menyampaikan informasi. Menurut Titus (dalam Arikunto,1998:138) metode adalah rangkaian cara dan langkah yang tertib dan terpola untuk menegaskan bidang keilmuan.

Penelitian atau riset berasal dari bahasa inggris research yang artinya adalah proses pengumpulan informasi dengan tujuan meningkatkan, memodifikasi atau mengembangkan sebuah penyelidikan atau kelompok penyelidikan.

Pada dasarnya riset atau penelitian adalah setiap proses yang menghasilkan ilmu pengetahuan. Adapun pengertian penelitian menurut para ahli yaitu Menurut Fellin, Tripodi dan Meyer (dalamListiyatiningsih dkk,2013:1), Penelitian adalah suatu cara sistematik untuk maksud meningkatkan, memodifikasi dan mengembangkan pengetahuan yang dapat di sampaikan (dikomunikasikan) dan diuji (diverifikasi) oleh peneliti lain.

Menurut Nasir (1988: 51), Metode penelitian merupakan cara utama yang digunakan peneliti untuk mencapai tujuan dan menentukan jawaban atas masalah yang diajukan.Beberapa pandangan metode penelitian secara umum menurut para ahli. Metode penelitian pada dasarnya merupakan cara ilmiah untuk mengumpulkan data dengan tujuan dan kegunaan tertentu. Cara ilmiah berarti kegiatan penelitian itu didasarkan pada ciri-ciri keilmuan yaitu rasional, empiris dan sistematis. 


\subsection{Sasaran Penelitian}

Sasaran dalam penelitian ini adalah Kajian Psikologi Para Pemain Band Sakadathu Dalam Musik Club Malam di Liquid Semarang.

\subsection{Lokasi Penelitian}

Dalam penelitian ini peneliti mengambil lokasi di liquid cafe Semarang Thamrin square, jln. MH Thamrin no. 5 Semarang, Indonesia 50132. Liquid Semarang merupakan salah satu club malam terbesar di kota Semarang.

\subsection{Metode Pengumpulan Data}

\subsubsection{Observasi}

Observasi adalah suatu teknik pengamatan yang dilakukan dengan sengaja dan sistematis terhadap gejala-gejala yang tampak pada objek penelitian (Rachman, 1993: 71).Teknik observasi dilakukan untuk memperoleh data yang diperlukan. Dalam penelitian ini, peneliti menggunakan teknik observasi. Maksudnya peneliti mengamati secara langsung kegiatan para pemain band Sakadathu. Selama mengamati, peneliti mengadakan pencatatan secara sistematis. Di samping itu peneliti juga menggunakan kamera foto untuk mendokumentasikan kegiatan-kegiatan dalam proses penelitian, untuk membantu keabsahan data yang telah diperoleh melalui observasi.

Observasi merupakan salah satu cara untuk mengumpulkan data dengan mengadakan pengamatan langsung terhadap obyek penelitian. Pengamatan dalam penelitian untuk mengamati kegiatan sehari-hari para pemain band Sakadath 
diantaranya yaitu latihan band, penampilan band, sarana prasarana di Liquid Semarang.

\subsubsection{Wawancara}

Teknik wawancara adalah suatu kegiatan yang dilakukan untuk memperoleh informasi langsung dengan cara mengajukan pertanyaan kepada informan. (Subagyo, 1991:39). Hal tersebut senada dengan pendapat Kartono, (1990: 187) yang menjelaskan bahwa teknik wawancara merupakan teknik percakapan atau Tanya jawab lesan antara dua orang atau lebih yang duduk berhadapan secara fisik, dan diarahkan ke dalam suatu permasalahan tertentu. Dalam proses wawancara terdapat dua pihak yang menempati kedudukan berbeda yang interview (penanya) dan interviewee atau pemberi jawaban (Kartono, 1993: 188). Interviewer mengajukan pertanyaan sambil menilai jawaban, mengadakan paraphrase (mengungkapkan isi dengan kata-kata lain), mengingat dan mencatat jawaban, serta menggali informasi lebih lanjut dengan berusaha memberi dorongan. Sedangkan interviewee atau information supplier (pemberi informasi) berkewajiban memberi keterangan atau penjelasan dengan cara menjawab semua pertanyaan yang diajukan interviewer.

Dalam penelitian ini digunakan teknik wawancara bebas terpimpin artinya dalam kegiatan wawancara tersebut pewawancara secara bebas atau santai mewawancarai informan menggunakan pedoman yang berisi sejumlah pertanyaan yang telah dipersiapkan mengenai Kajian Psikologi para pemain band Sakadathu dalam musik dunia malam di Liquid Semarang, Metode pencatatan 
dalam penelitian ini menggunakan beberapa media yaitu, media pencatat berupa buku tulis, perekam suara dan kamera digital, dengan menggunakan media tersebut terhadap para pemain band Sakadathu untuk mencari data sehari-hari, karakter dari tiap pemain dan Manager kafe Liquid Semarang untuk mencari data Sakadathu disaat perform di Liquid Semarang. Diharapkan dapat menghadirkan data yang jelas dan valid serta sebagai bukti dari pelaksanaan penelitian terhadap kajian psikologi para pemain band Sakadathu di Liquid Semarang.

\subsection{Teknik Studi Dokumentasi}

Teknik studi dokumentasi adalah teknik mencari data yang terdapat dalam catatan harian, transkrip, buku, surat-surat kabar, majalah, prasasti, notulen rapat, agenda dan sebagainya.(Arikunto, 1992: 200).Hal tersebut dilakukan untuk melengkapi data yang belum dikemukakan oleh informan, serta untuk mencek sejauh mana data-data yang telah diperoleh data dipertanggungjawabkan.

Teknik studi dokumenter dalam penelitian ini, dilakukan dengan mempelajari data anggota, catatan kegiatan-kegiatan yang telah dilakukan dalam pementasan band Sakadhatu , misalnya foto-foto kegiatan pementasan musik Sakadhatu, foto para personil band Sakadathu.

\subsection{Studi Pustaka}

Studi pustaka merupakan alat pendukung berupa buku atau artikel-artikel yang digunakan untuk mendukung memberikan penjelasan dan melengkapi segala hal yang berkaitan dengan penelitian yang dilakukan. 
Menurut Nazir (1998: 122) studi pustaka merupakan langkah yang penting dimana setelah seorang peneliti menetapkan topik penelitian, langkah selanjutnya adalah melakukan kajian yang berkaitan dengan teori yang berkaitan dengan topik penelitian. Dalam pencarian teori, peneliti akan mengumpulkan informasi sebanyak-banyaknya dari kepustakaan yang berhubungan. Sumber pustaka dapat diberoleh melalui : buku-buku jurnal, majalah, hasil-hasil penelitian (Tesis, dan Disertasi) dan sumber-sumber lainya yang sesuai (koran maupun internet).

\subsection{Teknik Analisis Data}

Teknik analisis data adalah cara menganalisis data yang diperoleh dari penelitian untuk mengambil kesimpulan hasil penelitian. Proses analisis data dengan menelaah seluruh data yang tersedia dari berbagai sumber yang telah diperoleh dari penelitian dilapangan, yaitu dari wawancara, pengamatan yang sudah dituliskan dalam catatan lapangan, dokumen pribadi, dokumen resmi, gambar, foto dan sebagainya (Moeloeng, 2000:190).

Analisa data adalah proses mencari dan menyusun secara sistematis data yang diperoleh dari hasil wawancara, catatan lapangan dan dokumentasi, dengan cara mengorganisasikan data ke dalam kategori menjabarkan ke unit-unit, melakukan sintesa, menyusun ke dalam pola, memilih mana yang penting dan yang akan dipelajari, dan membuat kesimpulan sehingga mudah dipahami oleh diri sendiri maupun orang lain (Sugiyono, 2013: 335).

Sugiyono (2013: 335) mengatakan bahwa analisis data kualitatif adalah bersifat induktif, yaitu suatu analisis berdasarkan data yang diperoleh, selanjutnya 
dikembangkan pula hubungan tertentu atau menjadi hipotesis. Pengertian analisis data menurut Koentcaraningrat (1991: 268). Menjadi dua macam yaitu kualitatif dan kuantitatif, perbedaan ini menurutnya tergantung dari sifat data yang dikumpulkan. Data yang bersifat monografis disebut analisis kuantitatif statistik, sedangkan yang berdasarkan pada data yang terkumpul disebut analisis kualitatif.

Dalam analisis ini, menurut Milles dan Huberman (2001: 21), teknik analisis data yang digunakanyaitu mencakup tiga komponen pokok yaitu :

\subsubsection{Reduksi Data}

Reduksi data merupakan proses pemilihan, pemutusan perhatian pada penyerderhanaan, pengabstrakan dan transformasi data kasar yang muncul dari catatan-catatan tertulis di lapangan. Reduksi data berkaitan erat dengan analisis data. Pilihan-pilihan peneliti tentang bagian data mana yang dipilih, data yang dibuang, cerita mana yang sedang berkembang itu merupakan pilihan-pilihan analisis. Reduksi data merupakan bentuk analisis yang menajamkan, menggolongkan,mengarahkan,membuang yang tidak perlu dan mengorganisasi sata dengan cara sedimikian rupa hingga kesimpulan finalnya dapat ditarik dan diverifikasi.

\subsubsection{Sajian Data}

Penyajian data merupakan sekumpulan informasi yang terkumpul dan memberikan kemungkinan adanya penarikan kesimpulan dan pengambilan tindakan. Penyajian yang sering digunakan dalam penelitian kualitatif adalah 
bentuk wancana naratif (penceritaan kronologis) yang merupakan penyerderhanaan dari informasi yang banyak jumlahnya ke dalam kesatuan bentuk yang disederhanakan.

\subsubsection{Penarikan Kesimpulan}

Kegiatan verifikasi merupakan kegiatan yang sangat penting, sebab dari awal pengumpulan data, seorang penganalisis kualitatif harus mampu mencari bendabenda, mencatat keteraturan, pola-pola, konfigurasi yang semua itu merupakan satu kesatuan yang utuh, barangkali ada keterkaitan alur, sebab akibat preposisi.

Dalam penelitian ini data yang diperoleh bersifat kualitatif. Oleh karena itu analisis data yang digunakan adalah sesuai dengan data kualitatif, yaitu analisis deskriptif kualitatif. Proses analisis data ditempuh melalui proses reduksi data, sajian data dan penarikan kesimpulan dan verifikasi.

Reduksi data merupakan data yang diperoleh melalui observasi atau pengumpulan dokumen yang masih berupa uraian panjang dan perlu direduksi. Menurut Milles dan Huberman (2001: 23)mereduksi data diartikan sebagai proses pemilihan, pemusatan perhatian, pengabsahan dan transformasi data kasar yang muncul dari catatan-catatan yang muncul di lapangan. Data-data tersebut dipisahkan sesuai dengan permasalahan yang dimunculkan kemudian dideskripsikan, diasumsi, serta disajikan dalam bentuk rupa sehingga kesimpulan finalnya dapat ditarik dan diverifikasikan.

Berdasarkan pendapat-pendapat diatas, maka dapat disederhanakan dalam pengertian bahwa sejumlah data yang terkumpul melalui teknik wawancara, 
teknik observasi, dan dokumentasi digabung menjadi satu kemudian dicoba untuk dibakukan dan diolah serta dipilah-pilah menurut jenis-jenis atau golongan pokok bahasannya. 


\section{BAB 4}

\section{HASIL PENELITIAN DAN PEMBAHASAN}

Berdasarkan hasil observasi, wawancara, dan analisis data secara deskriptif kualitatif dapat disampaikan hasil penelitian secara berurutan diawali dari gambaran umum liquid semarang, deskripsi informan, karekter psikologi personil dan kemampuan bermusik personil.

\subsection{Gambaran Lokasi Penelitian}

Liquid Semarang berada di tengah-tengah ruang publik kota Semarang, Liquid Semarang didirikan pada tanggal 3 oktober 2009. Liquid Semarang terletak di Thamrin Square 2nd Floor, Jl. MH Thamrin no 5 Semarang. Saat ini liquid memiliki kurang lebih 25 karyawan yang terdiri dari Owner, Manager kafe, Public Relation 4orang, Keamanan 4orang, barista 4orang, waitress 10orang. Liquid merupakan tempat hiburan malam yang popular disemarang, pada hari biasa tidak kurang dari 300 pengunjung mendatangi liquid, dan disaat event pengunjung yang datang bisa mencapai 500 orang. Pengunjung liquid didominasi kalangan mahasiswa, khususnya pada hari senin dimana tema yang di suguhkan adalah campus party. Gambar lokasi liquid dapat dilihat pada gambar dibawah ini. 


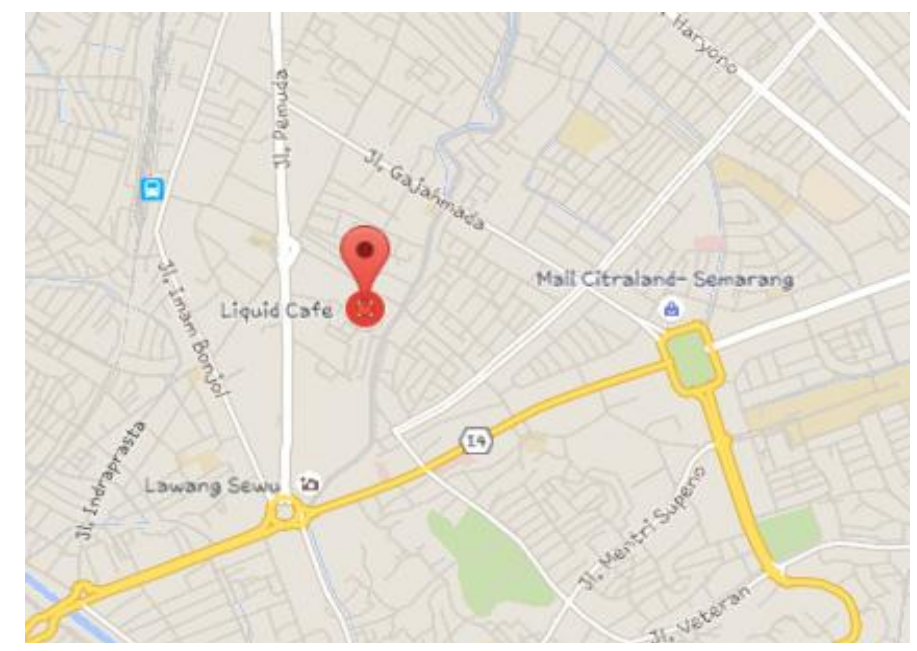

\section{Gambar 4.1 Denah Lokasi Liquid Semarang} (Sumber : Adhadiantin, 2015)

Liquid tiap minggunya mengadakan acara-acara besar berskala international dengan mengundang $\mathrm{Dj}$ luar negeri. Untuk acara regular disuguhkan dengan acara musik berkualitas dari Home Band mereka. Selain itu Liquid mempunyai dua area yang mempunyai kualitas harga yang berbeda, yaitu sofa atas dinana pengunjung dapat menikmati pemandangan seluruh dance floor serta both Dj dengan leluasa. Pemesanan untuk sofa atas dapat dilakukan dengan minimum pemesanan diatas Dua Juta Rupiah fasilitas VIP. Adapun area keduanya yaitu area dance floor, dengan pemesanan diatas Dua Ratus Ribu Rupiah.

Liquid merupakan club malam di Semarang yang sangat popular. Dengan harga tiket masuk yang terjangkau, Liquid tetap mengutamakan kualitasnya. Seperti minuman beralkohol yang diambil dari luar negeri, kemudian pelayanan yang sangat baik. Tata panggung dengan banyak speaker, tata lampu dengan banyak warna membuat para pengunjung terpesona dan terlena. Disamping itu Liquid mempunyai design bar yang menarik. Dengan banyak lampu hias dan 
aksesori botol-botol minuman yang menempel didinding. Berikut gambar tata ruang Liquid Semarang.

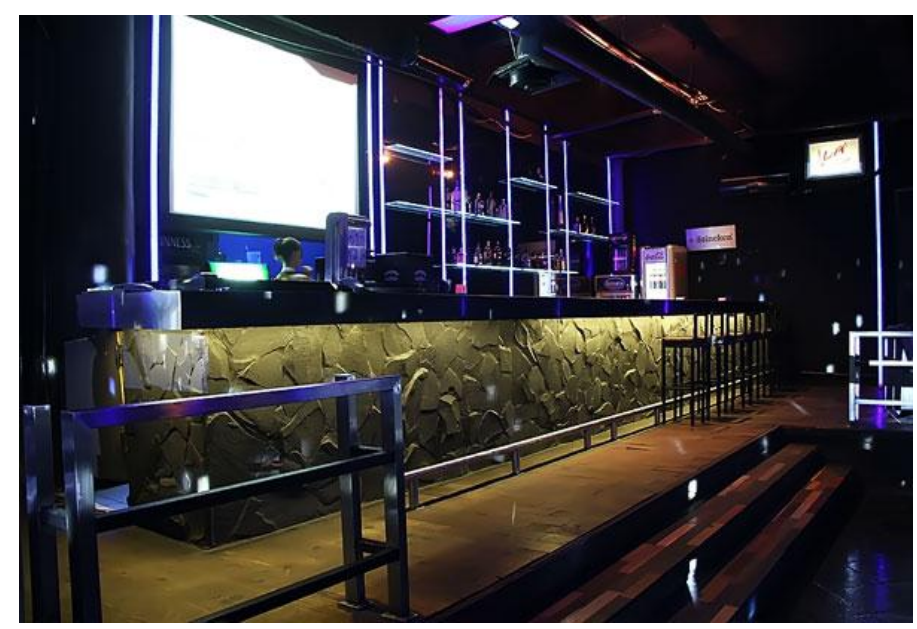

Gambar 4.2 Liquid Semarang (Sumber : Adhadiantin, 2015)

\subsection{Profil Sakadathu Band}

\subsubsection{Latar Belakang Band Sakadathu}

Sakadhatu terbentuk November 2009. Awalnya Sakadathu merupakan band dari kuliah yang mereka bentuk untuk mengikuti acara band disalah satu kampus mereka. Sakadathu dibentuk oleh Hary Chetot, yang sekarang menjadi manager Sakadathu. Awalnya Personil Sakadatu beranggotakan Pungky (bass dan vokal), Inu (drum), Vientan (keyboard), Adhi (keyboard). Mereka membentuk band Sakadatu dengan tujuan mengikuti festival band di kota-kota Jawa Tengah.

Sakadathu sering menjuarai festival Band antar mahasiswa dikarenakan para pemain mempunyai skill yang mumpuni. Seiring dengan berjalannya waktu, 
Sakadathu sering dijadikan bintang tamu diacara Festival Band Umum Se- Jawa Tengah.

Manager Sakadathu ( Hary Chetot) akhirnya mulai mengajak para pemain untuk menjadi lebih maju lagi daripada sebelumya. Dengan cara memasukan profil band Sakadathu ke kafe-kafe dikota Semarang. Pada saat itu mereka mulai memikirkan untuk menambah personil yaitu vokalis, akhirnya mereka memasukan sekaligus tiga vokalis, karena tuntutan dari pihak kafe yang meminta untuk menambah vokalis. Tiga vokalis tersebut diantaranya (Dino, Girdha, Helga). Mereka menamakan band Sakadhatu dengan bahasa sansekerta yang artinya pondasi, dalam mereka bermusik dan memilih nama yang unik menjadikan mereka lebih unggul dibandingkan dengan band pesaing mereka meskipun mereka sama-sama membawakan musik R\&B sebagai aliran mereka bermusik.

Konsep utama mereka sejak terbentuk adalah menjadi sebuah band longtrip yang solid, hingga saat ini Palu, Samarinda, dan Semarang, masih menjadi kota tujuan mereka dalam bermusik tak puas dengan kemampuan mereka saat ini, Hard Rock Cafe Bali, menjadi motifasi meraka untuk terus berkembang dan menjadi band yang lebih baik.

Sakadathu masih bertahan menjadi home band diliquid cafe Semarang di 2nd floor, Thamrin square, jln. MH Thamrin no. 5 Semarang, Indonesia 50132. Informan dalam penelitian ini terdiri dari 1 orang manajer kafe liquid Semarang dan 5 orang personil sakadhatu diantaranya adalah Girda sebagai vocalist 25 (tahun), Pungky sebagai bassis (25tahun), Ardhi gitaris (27 tahun), Vientan 
sebagai keyboard (26 tahun) dan Inu sebagai drummer (24 tahun). Dari ke lima personil sakadhatu hanya Ardhi satu-satunya personil yang sudah berumah tangga.

Latar belakang personil sakadhatu ditinjau dari perjalanan hidupnya cukuplah bervariasi. Vokalis sakadhatu yang merupakan satu-satunya personil wanita di grup band ini pernah bersekolah musik di Jakarta, sementara Pungky, Ardhi, dan Inu awalnya menjadikan musik sebagai hobi saja dan kini musik bagi mereka adalah pekerjaan, entah sampai kapan. Personil sakadhatu semuanya berdomisili di Semarang, diantara mereka sudah memiliki rumah disemarang dan sebagian lagi tinggal di mesh yang disediakan oleh liquid.

Personil sakadhatu kerap kali bermain solo, tergantung job dilapangan, dari kelima personil tersebut yang paling sering bermain solo adalah Girdha selaku vokalis sakadhatu, selain cantik, energik dan bersuara asik, Girdha memang memiliki latar belakang pendidikan seni sehingga kemampuannya dalam menyesuaikan diri pada tema acara sangat baik. Vientan selaku keyboardis sakadhatu juga sering diundang sebagai solo. Namun demikian mereka tetap kompak dan konsekuensi pada grup band yang telah mereka dirikan.

\subsubsection{Susunan Pemain Band Sakadathu}

Sakadathu beranggotakan 7 orang, yaitu: (1) Dino Adi Putro $29^{\text {th }}$ Semarang, Gabriella Girdha Lanteng $26^{\text {th }}$ Jakarta, Helga Arum $25^{\text {th }}$ Semarang sebagai vocal; (2) Kidung Ardhi Khalifa $28^{\text {th }}$ Semarang sebagai Guitarist; (3) Pungky Tri Cahyono $25^{\text {th }}$ Semarang sebagai Bassist; (4) Vientan Dionisius $28^{\text {th }}$ 
Semarang sebagai Keyboardist; (5) Lazuardy Wisnhu Bahtiar $25^{\text {th }}$ Semarang sebagai Drummer.

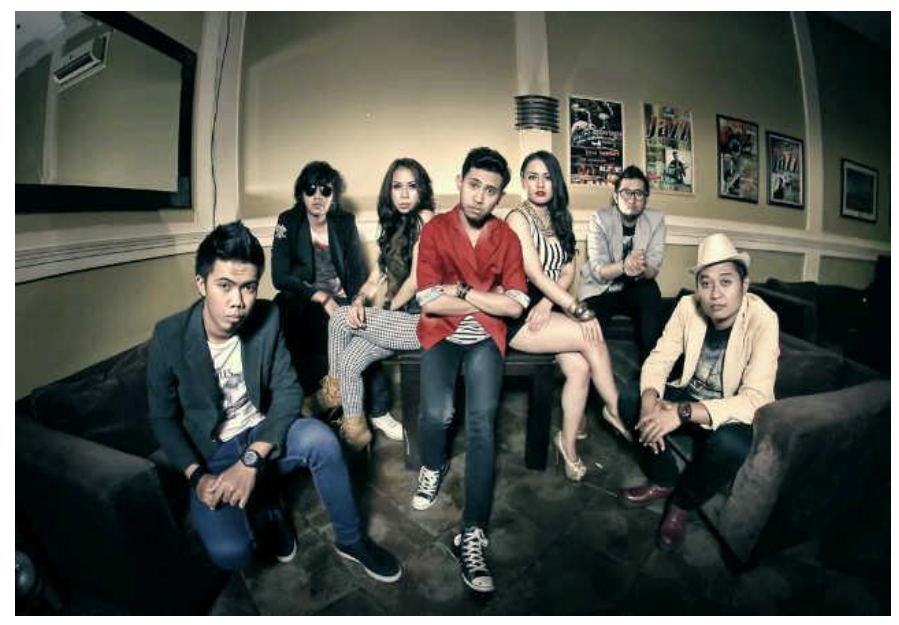

Gambar 4.3 Sakadathu

(Sumber : Adhadiantin, 2015)

\subsubsection{Kegiatan Sehari-hari Band Sakadathu}

Selain menjadi Homeband di Liquid Café Semarang, Band Sakadathu mempunyai jadwal setiap hari Sabtu dan Minggu yaitu mereka mengisi acara di pernikahan-pernikahan sebagai band acoustic wedding. Kemudian di hari biasa mereka mengambil job untuk mengisi acara di gathering kantor-kantor yang ada di Semarang.

Jadwal Sakadathu terhitung padat dikarenakan mereka bekerjasama dengan salah satu EO (Event Organizer) di Kota Semarang sehingga Sakadathu mempuyai banyak jadwal panggung untuk memenuhi kebutuhan para personil band. Untuk menunjang penampilan mereka saat di panggung, Sakadathu mempunyai jadwal rutin latihan band pada Hari Rabu di BM Studio Musik yang 
bertempat di Jl. Sampangan Semarang. Dengan jadwal latian rutin skill mereka tetap terjaga.

Sakadathu dituntut untuk mempunyai penampilan yang fresh, dengan melakukan berbagai cara. Seperti ke Salon untuk perawatan wajah maupun rambut. Sebagai pekerja seni, Sakadathu terlihat fashionable. Mereka memperhatikan kostum saat pentas, setiap minggu mereka mempunyai tema dalam berkostum. Seperti tema hawai, koboi, anak sekolah dll. Berikut gambar Penampilan Sakadathu.

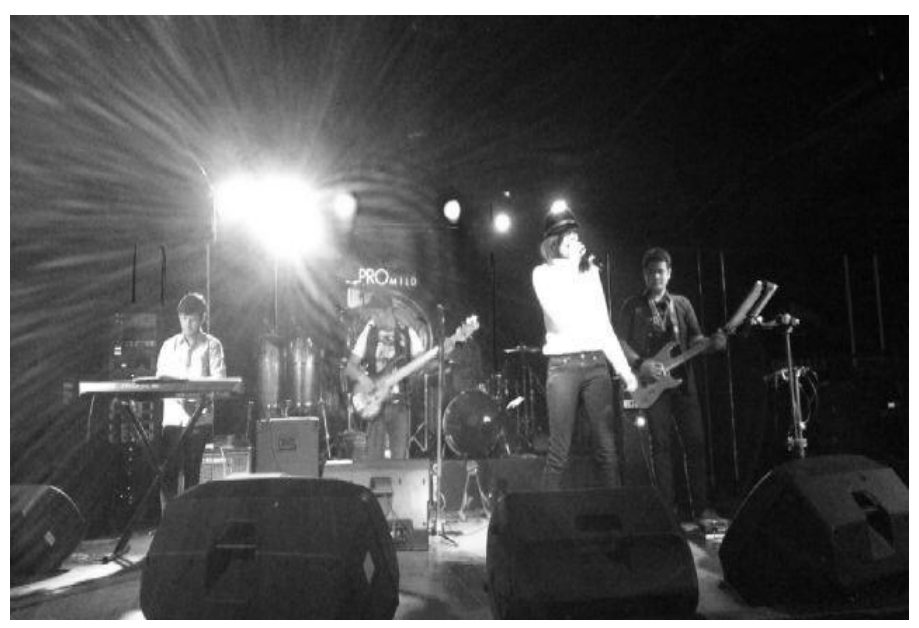

Gambar 4.4 Profil Sakadathu (Sumber : Adhadiantin, 2015)

\subsection{Karakter psikologis personil sakadhatu}

Grup band sakadhatu kerap kali tampil malam hari di liquid café. Kondisi malam yang gelap dingin ditambah keras nya musik dan berbagai aroma alkohol di liquid memaksa para personil untuk menyesuaikan diri dengan keadaan ini meskipun hati mereka tak selalu menerima keadaan ini. 


\subsubsection{Karakter psikologis vokalis sakadathu}

Vokalis bisa diibaratkan sebagai roh dari grup band, suatu grup band akan bagus jika memiliki vokalis yang handal baik saat menyanyikan lagu maupun saat menguasai panggung. Untuk melakukan dua hal ini diperlukan mental yang kuat disamping skill yang hebat. Girdha vokalis sakadathu tak henti-hentinya menghibur penonton liquid saat menyanyikan lagu, mulai dari lagu dangdut, Ska hingga reggae. Girdha selalu melakukan interaksi dengan penonton sehingga suasana malam di liquid pun seakan-akan menjadi damai, seakan-akan menjadi surga kebebasan bagi para pengunjungnya. Pungky, Ardhi, Vientan dan Inu tak hentinya-hentinya memainkan musik, mengiringi girdha yang sedang asyik menyanyi menghibur para penonton. Ini menunjukan bahwasanya personil sakadhatu sangat solid dan professional dalam memainkan pentasnya.

Waktu yang diberikan pihak manajemen liquid untuk sekali sesi adalah 45 menit, namun terikan penonton yang belum mencapai klimaks kepuasan saat sesi menjelang habis memotivasi manajeer untuk memberikan sesi tambahan pada personil sakadhatu untuk terus mengalunkan lagunya tentu dengan iming-iming tambahan fee yang menjanjikan. Alhasil merekapun memainkan musik hampir 2 jam dalam satu periode waktu, ini semua dilakukan demi uang, demi kepuasan pengunjung dan demi loyalitas sakadhatu pada liquid café.

Fakta diatas menunjukan personil sakadathu memiliki karakter psikologi kepribadian yang baik, mereka loyal pada pekerjaannya meskipun keloyalan ini bisa berdampak kurang pada kesehatannya mengingat malamhari sebenarnya waktu yang lebih tepat digunakan untuk istirahat dianding untuk bekerja. Secara 
garis besar karakter psikologis personil sakadathu dapat dibedakan menjadi tiga kelompok besar diantaranya adalah karakter berdasarkan perform, karakter psikologis ditinjau dari jenis musik yang dibawakan dan karakter psikologis personil ditinjau dari tempak kerja.

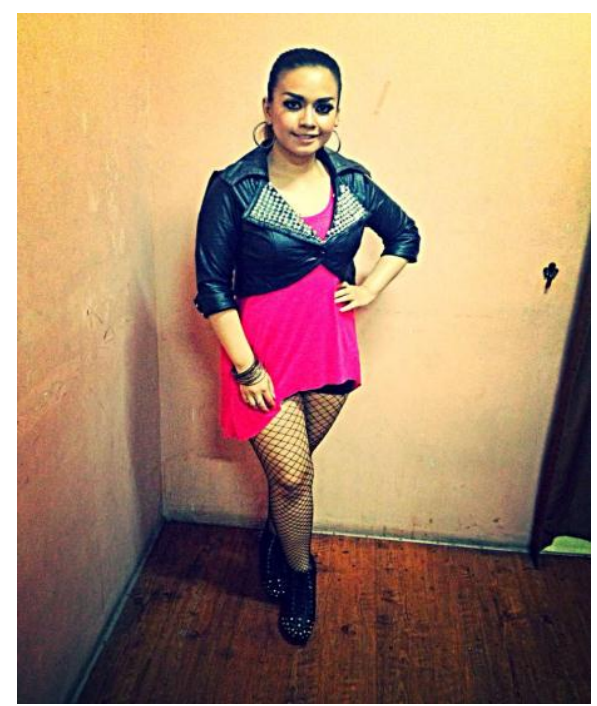

Gambar 4.5 Girdha vokalis (Sumber : Adhadiantin, 2015)

\subsubsection{Karakter Psikologis Bassist Sakadathu}

Bassist sakadhatu di percayakan pada Pungky, Pungky merupakan bassist yang handal, umurnya baru 25 tahun dan sudah 4 tahun Pungky bergabung dengan sakadathu. Saat vokalis memilih rehat sejenak Pungky kerap kali mengisi kekosongan dengan memainkan bassnya sebagai upaya untuk menjaga hidupnya suasana. Pungky tidak pernah mengenyam pendidikan musik dia lulusan SMA namun kesenangannya pada musik membuat dia ahli dalam bermain musik.

Sebagian orang bekerja karena ingin mendapatkan uang semata, dilihat dari tujuan Pungky bermain musik, ia memiliki tujuan yang sangat kompleks, 
selain mencari uang Pungky juga ingin menambah pengalaman dan menambah relasi. Sangat masuk akal mencari relasi di liquid mengingat yang berkunjung disana rata-rata dari kalangan atas. Banyak teman menambah lebih banyak wawasan, kematangan psikologis seseorang pun dapat dibentuk melalui interaksi sosial.

Di Sakadathu, Pungky mempunyai peranan yang sangat penting. Selain Manager, Pungky seringkali mencarikan job untuk Sakadathu. Dikarenakan sifat yang mudah bergaul membuat dia mempunyai banyak teman Banyak event-event yang ditawarkan Pungky, seringkali mendapat event besar. Berkat Pungky, Sakadathu mendapat kesempatan dapat bermain musik di Singapura. Secara tidak langsung Sakadathu mendapat banyak tambahan materi berkat Pungky..

Pungky menyukai grupband Red Hot Chile Paper, suatu grup band legendaris yang liriknya didominasi cerita tentang kebebasan berpikir dan keinginan untuk tidak diusik orang lain. Secara umum karakter seseorang akan mengikuti idolanya, ini berarti ada kemungkinan pungkypun ingin menerapkan pesan yang disampaikan pada lagu-lagu yang dibawakan oleh Red Hot Chile Paper jika ia benar-benar mengetahui artinya yang memang dibawakan dengan bahasa inggris. Tidak dapat dipungkiri sebagai masyarakat Indonesia menyukai lagu barat karena alunan musik dan suara vokalisnya enak untuk dinikmati bukan karena pesan yang terkandung dalam lagu tersebut, dan Pungky juga orang Indonesia. 


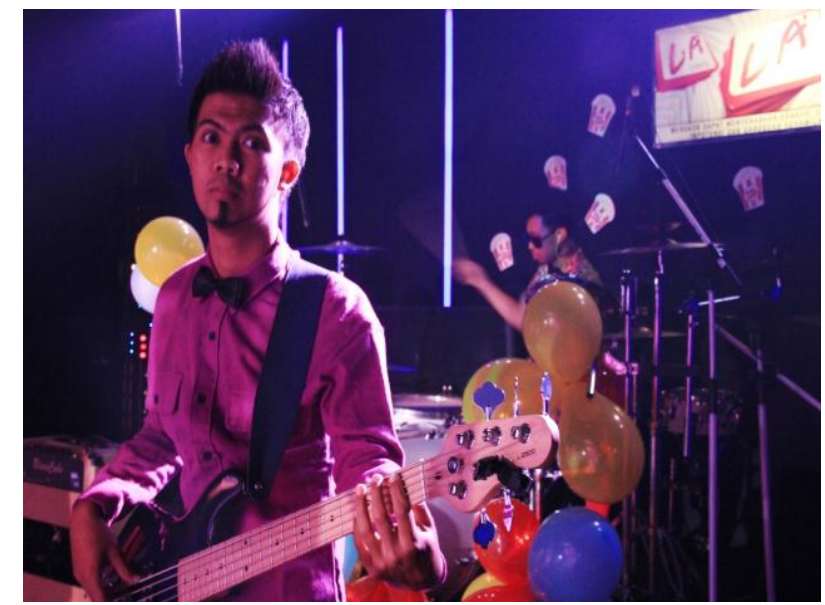

Gambar 4.6 Pungky Bassist (Sumber : Adhadiantin, 2015)

\subsubsection{Karakter Psikologis Gitarist Sakadathu}

Gitaris dalam suatu grup band biasanya merangkap sebagai pencipta lagu, begitu juga dengan grup band sakadathu, hampir semua lagu pribadi grup band sakadathu diciptakan oleh Ardhi gitaris Sakadathu. Ardhi mempunyai kesukaan terhadap musik rock. Ardhi sangat mendalami music rock, dilihat dari banyaknya penghargaan dan piala yang didapat pada saat mengikuti festival pada saat bersekolah. Ardhi pun rela membeli cd album yang dipesan secara online dari luar negeri, walaupun harga relatif mahal. Untuk kecintaannya pada band tersebut, Ardhi rela mengeluarkan banyak uang. Seperti membeli tiket konser, kaos, dll. Kemampuannya mengiringi vocalis menjadikan pertunjukan diatas panggung lebih meriah. Ketika vokalis mengulur ngulur lagu dalam rangka menghibur pengunjung ardhi dengan sabar tetap mengirinya, bahkan saat terjadi ketidakpatuhan perilaku penonton pada vokalis Sakadathu ardhilah yang pertama kali menghalaunya. Dibanding dengan pemain lain posisi Ardhi dipanggung 
paling dekat dengan vokalis, apa yang dilakukan Ardhi menunjukan dia memiliki karakter yang peduli terhadap teman saat berada di atas panggung.

Dalam kehidupan sehari-hari ardhi terkenal humoris, mudah bergaul dan easy going, namun dibalik itu semua ia termasuk orang yang temperamental, sering berusaha memaksakan pendapatnya pada sesama anggota grup band saat menseting sebuah acara panggung. Keahlian Ardhi dalam merancang suatu pegelaran panggung membuat teman-temannya mempercayakan ardhi sebagai decisional maker dalam hal pagelaran meskipun mereka juga harus menyesuaikannya dengan tema yang ada. Ide yang dikeluarkan Ardhi sering kali membuat personil lain menjadi bangga karena kecerdasannya. Untuk masalah pengelolaan uang ardhi termasuk orang yang konsumtif. Mudahnya mencari uang didunia musik malam dan statusnya yang masih lajang sangat menunjang dirinya untuk hidup konsumtif.

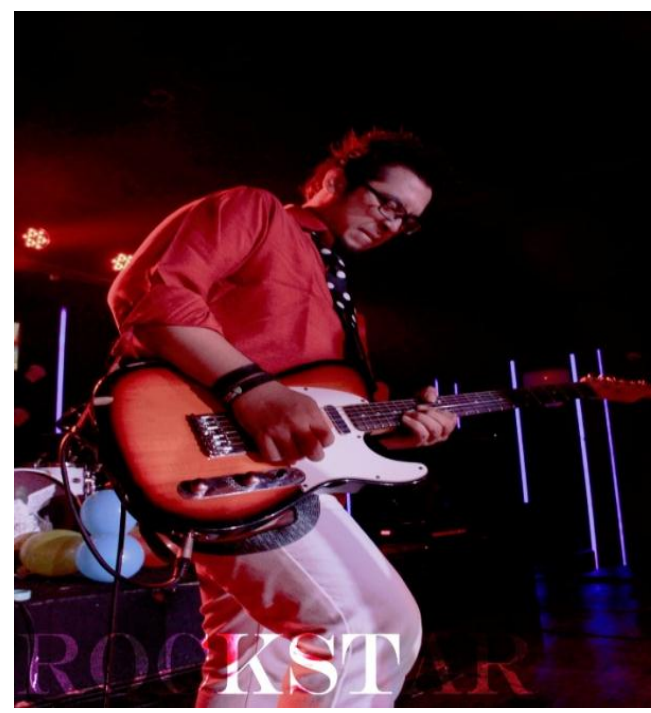

Gambar 4.7 ArdhiGitarist (Sumber : Adhadiantin, 2015) 


\subsubsection{Karakter Psikologis Keyboardist Sakadathu}

Keyboard dalam grup band sakadhatu digunakan sebagai pengganti melody, tanpa pemain keyboard alunan musik yang dimainkan grup band ini mungkin sangat hambar. Vientan (26 tahun) adalah orang yang dipercaya grup band untuk memainkan keyboard, Vientan memiliki keahlian yang cukup mumpuni dalam bermain, terbukti dengan banyaknya tawaran dari pihak luar untuk tampil secara solo, beberapa tawaran tampil secara solo dengan jadwal yang tidak berbenturan dengan jadwal manggung sakadathu ia ambil dan yang berbenturan ia batalkan. Ini menunjukan Vientan memiliki jiwa kebersamaan yang tinggi.

Statusnya yang sudah berkeluarga membuat Vientan tidak memiliki jiwa konsumtif layaknya anggota yang lain. Vientan dapat mengontrol kebutuhan apa saja yang perlukan, jika tidak penting dihiraukan. Vientan selalu ingat anak dan istrinya, sering kali vientan mendapat banyak. Seperti minuman alkohol yang sering diberi oleh tamu, vientan selalu menolak dengan sopan.Vientan lekas pulang ketika bekerja di Liquid sudah selesai dikarenakan ada keluarga yang menunggu dirumah. Namun demikian tidak membuat kebersamaan grupband Sakadathu menurun. Antar anggota saling mengerti kepentingan pribadi sesama anggotanya, mereka tidak memaksakan diri untuk selalu berkumpul, setelah acara panggung selesai maka sampailah pada saat perpisahan.

Didalam Sakadathu, Vientan terkadang menjadi orang yang dituakan karena vientan sangat bijaksana dalam mengatasi masalah yang ada pada Sakadathu. Disaat personil lain yang sering berbeda pendapat dan salah paham, 
Vientan selalu menjadi penengah. Jika ada rapat dalam Sakadathu Vientan ditunjuk sebagai pengambil keputusan, dikarenakan kedewasaan dan bijaksana membuat vientan disegani oleh personil lain.

Vientan terlihat lebih bersahaja, bahkan di panggung tidak banyak gerakan akrobatik yang dipertontonkannya, lebih cenderung diam. Namun demikian ini tidak mengurangi kualitasnya di atas panggung. Mungkin Vientan sangat mengetahui yang paling pokok untuk bagi seorang keyboardis adalah keselarasan antara melodi dan lagu bukan aksi akrobati karena yang lebih berhak untuk melakukan aksi akrobatik lebih adalah vokalis meskipun sesekali gitaris dan drummer juga sesekali melakukannya.

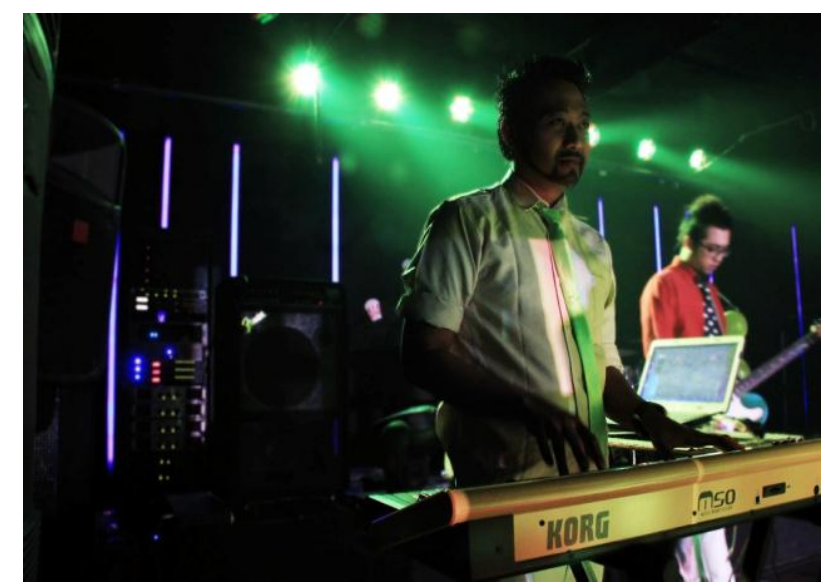

Gambar 4.8 Vientan Keyboardist (Sumber : Adhadiantin, 2015)

\subsubsection{Karakter Psikologis Drummer sakadathu}

Drummer merupakan objek vital dalam suatu grup band khususnya grup band sakadhatu, tanpa drummer yang handal musik yang dilantunkan terkesan kurang menggigit. Inu adalah orang yang dipercaya grup band sakadhatu sebgai drummer, dipanggung inu dikenal sebagai orang yang berapi-api penuh semangat 
dalam memukul drumnya. Berbagai macam aksi akrobatik sering ia tunjukan mulai dari memutar-mutar stik drum, memukul drum sambil memutari drum, beberapa kali Inu memukul dirinya sendiri dengan stik ini dilakukan demi kepuasan pengunjung liquid café.

Inu dikenal sebagai seorang yang glamor, konsumtif dan hobi membelanjakan hasil kerjanya.Tidak berbeda dengan anggota grup band lainnya, Inu menjadikan pekerjaannya sebagai tempat mencari uang, menambah relasi dan meningkatkan performanya. Fakta ini menunjukan inu memikirkan masa depannya, ia sadar bahwa dengan menambah relasi informasi dan pekerjaan lebih mudah untuk didapatkan.

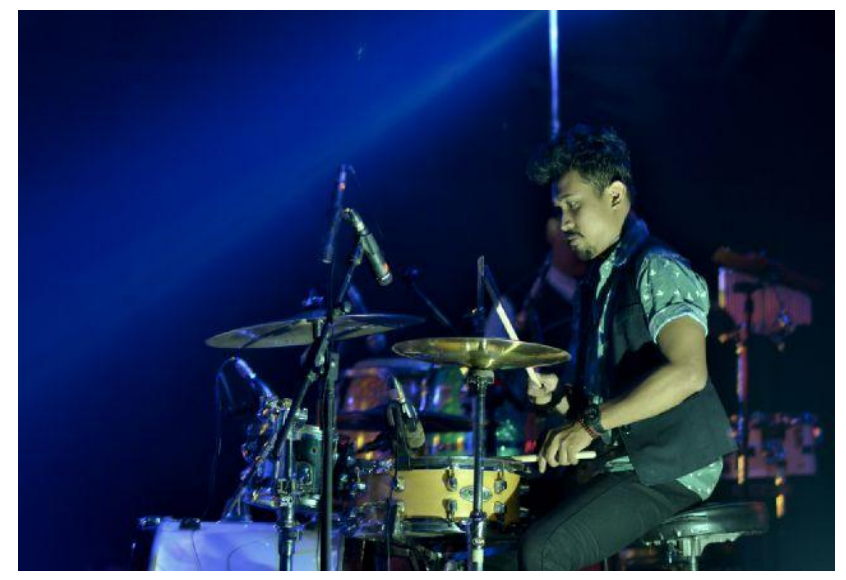

Gambar 4.9 Inu Drummer (Sumber : Adhadiantin, 2015)

\subsection{Karakter psikologis personil sakadhatu ditinjau dari perform diatas} panggung

Perform merupakan aspek yang sangat menentukan baik-buruknya penilaian audiensi pada personil grup band, perform yang bagus, energik, ada 
unsur interaksi dengan pengunjung, penuh dengan antraksi biasanya lebih menghibur audien dibandingkan dengan grup band yang tampil secara kaku. Penampilan sakadathu sangat memukau pengunjung, inilah penilaian yang diutarakan oleh manajer liquid, fakta ini didukung dengan dijadikannya sakadhatu sebagai salah satu grup band yang menghiasi panggung liquid secara rutin.Dalam 1 bulan sakadathu bisa tampil lebih dari 8 kali di liquid, ini artinya dalam waktu satu minggu grup band ini bisa tampil lebih dari 2 kali.

Sakdathu merupakan grup band yang lengkap selain berkualitas mereka juga memiliki karakter pribadi yang unik, hal ini seperti yang diutarakan manajer liquid, saat diwawancarai mengenai kualitas perform dari grup band sakadathu ia berkata

"Selain Sakadathu merupakan salah satu band yang berkualitas, mereka mempunyai karakter tersendiri untuk menjadi band longtrip yang pantas berada di Liquid . Kerena untuk diketahui sendiri Liquid merupakan salah satu club terbesar dan ternama di kota Semarang. Disamping itu Sakadathu mempunyai manajer band yang cerdas untuk mempresentasikan profil band Sakadathu."

Kemampuan manajerial sakadhatu dan kemampuan personil sakadhatu dalam meyakinkan seseorang menjadi nilai tambah bagi mereka dalam menunjung perform di panggung. Saat melakukan perform grup band ini sangat menguasai panggung bahkan pandai membaca kondisi lingkungan. Sakadathu akan memainkan lagu-lagu slow ketika ada indikasi ketidak kondusifitasan peran pengunjung, ini dilakukan untuk mencegah terjadinya kerusuhan mengingat musik keras merupakan cara yang cukup ampun dalam hal memancing keributan. Ketika keributan benar-benar terjadi maka grup band ini sejenak menghentikan penampilanya dan memulai lagi ketika lingkungan sudah kondusif. Fakta ini 
menujukan bahwa grupband ini memiliki kemampusan psikologi yang bagus dalam mengendalikan diri meskipun sedang berekspresi.

Campbell (2001) menjelaskan bahwa musik dapat menyeimbangkan gelombang otak. Gelombang otak dapat dimodifikasi oleh musik ataupun suara yang ditimbul- kan sendiri. Kesadaran biasa terdiri atas gelombang beta, yang bergetar dari 14 hingga 20 hertz. Gelombang beta terjadi apabila kita memusatkan perhatian pada kegiatan sehari-hari di dunia luar, juga ketika kita mengalami perasaan negatif yang kuat. Ketenangan dan kesadaran yang meningkat dicirikan oleh gelombang alfa, yang daurnya mulai 8 hingga 13 hertz. Periode-periode puncak kreativitas, meditasi dan tidur dicirikan oleh gelombang theta, dari 4 hingga 7 hertz, dan tidur nyenyak, meditasi yang dalam, serta keadaan tak sadar menghasilkan gelombang delta, yang berkisar dari 0,5 hingga 3 hertz. Semakin lambat gelombang otak, semakin santai, puas, dan damailah perasaan, itu menurut cambel walaupun faktanya diluar panggung personil sakadathu juga terkadang tak bisa mengontrol pengeluaran khususnya saat mendapatkan banyak fee dari penonton papan atas.

Campbell (2001) selanjutnya menerangkan bahwa musik memiliki beberapa manfaat, yaitu: (1) musik menutupi bunyi dan perasaan yang tidak menyenangkan; (2) musik dapat memperlambat dan menyeimbangkan gelombang otak; (3) musik mempengaruhi pernapasan; (4) musik mempengaruhi denyut jantung, denyut nadi, dan tekanan darah; (5) musik mengurangi ketegangan otot dan memperbaiki gerak serta koordinasi tubuh; (6) musik juga mempengaruhi suhu badan; (7) musik dapat mengatur hormon-hormon yang berkaitan dengan 
stres; (8) musik dapat memperkuat ingatan dan pelajaran; (9) musik mengubah persepsi kita tentang waktu; (10) musik meningkatkan asmara dan seksualitas.

Point ke 10 dari penjabaran Cambell benar-benar terjadi di Liquid. Hampir semua pengunjung gairah seksualitasny meningkat, bahkan beberapa dari mereka tak ingin mengingat kejadian yang baru saja terjadi. Kemampuan grup band dalam membawakan musik mampu membius pengunjung liquid, mereka benar-benar dibuat mabok oleh musik yang dibawakannya, seakan-akan Girdha selaku vokalis sakadathu mampu membawa angan pengunjung kemanapun ia mau. Ini juga menunjukan bahwasanya personil sakadathu secara psikologis memiliki karakter yang sangat kuat dalam mempengaruhi orang lain. Perform grup band sakadathu dapat dilihat pada gambar dibawah ini.

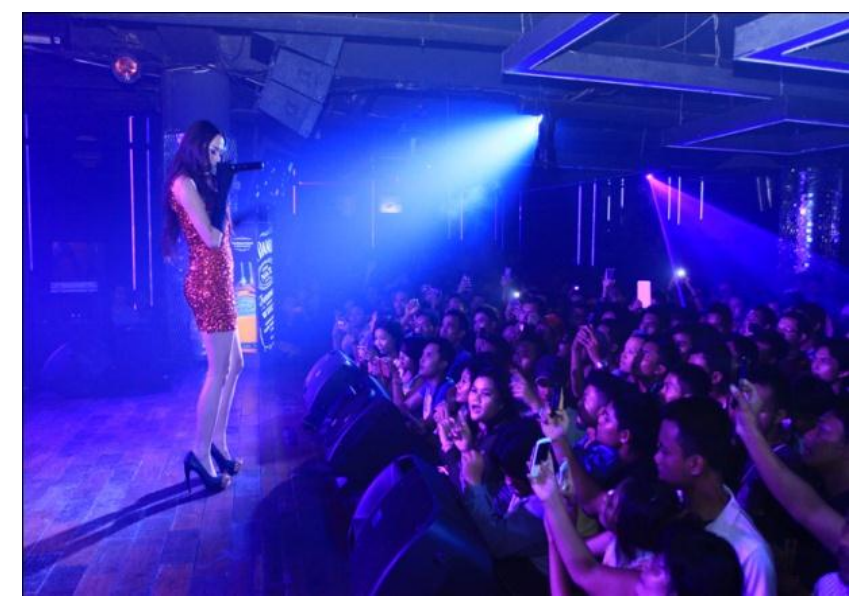

Gambar 5. Perform Sakadhatu Di Liquid (Sumber : Adhadiantin, 2015)

Dari gambar diatas terlihat interaksi positif penonton atas penampilan saskadhatu dalam membawakan musik di liquid cafe.Penonton sangat terhibur atas penampilan mereka, vokalis sakadathu juga sangat pandai dalam membius penonton untuk bersama-sama bersatu dalam alunan musik yang mungkin 
memang tak dimengerti oleh sebagian besar pengunjung kafe. Kesiapan mental yang bagus dari personil sakadathu membuat perform mereka enak untuk dinikmati. Kemampuan tiap-tiap personil dalam menjalankan tugasnya terlihat sangat padu, mereka tidak hanya membawakan lagu sesuai versi aslinya tetapi berdasarkan aransemen yang telah mereka buat dengan kombinasi-kombinasi yang tepat untuk berdansa.

\subsection{Karakter psikologis personil sakadathu ditinjau dari musik yang dibawakan diatas panggung}

Kondisi psikologis personil grup band bisa dilihat dengan membandingkan music yang biasa dinyanyikan dengan music yang paling disukain untuk dinyanyikan. Hasil penelitian menunjukan music yang paling sering dinyanyikan oleh grup sakadathu adalah RnB Hits seperti Titanium, Roar, Maps, Sugar dan lagu pop Indonesia, sedangkan musik yang paling disukai oleh kebanyakan personil band sakadathu adalah musik $\mathrm{RnB}$ dan pop Indonesia. Hasil ini menujukan ada kesesuaian antara musik yang disukai dengan musik yang biasa dibawakan. Adanya kesesuaian ini biasanya akan berefek pada kestabilan emosional para pemain. Berbagai teori psikologis menyebutkan terjadinyqa stress kerja biasanya disebabkan oleh terlalu banyak intensitas pekerjaan yang tidak sesuai dengan selera hati.

Musik RnB merupakan musik yang berasal dari orang kulit hitam, mereka merindukan kebebasan berekspresi, rindu akan kehidupan yang lebih baik, buah dari karya mereka adalah musik $\mathrm{RnB}$, para pecinta musik $\mathrm{RnB}$ pun biasanya tidak 
beda jauh dari hal ini, biasanya pecinta musik RnB cenderung lebih percaya diri, punya integritas namun sulit untuk diatur-atur, inilah sosok pemimpin. Penilaian ini didukung dengan fakta dilapangan bahwasanya pesonil grup band sakadhatu memainkan musik dengan penuh kepercayaan diri.Penggemar musik RnB biasanya didominasi oleh masyarakat ekonomi kelas menengah hingga kelas atas, kalangan inilah yang biasanya memenuhi liquid cafe yang diantara mereka akhirnya menjadi teman personil sakadathu. Dari sinilah timbul gaya hidup hedonis meracuni sebagian personil sakadhatu.

\subsection{Karakter psikologis personil sakadathu ditinjau dari tempat kerja.}

Liquid cafe merupakan tempat hiburan malam paling popuker di kota semarang meskipun ini bukan yang paling elit. Tidak dapat pungkiri lingkungan merupakan aspek krusial dalam pembentukan dan pertumbuhan psikologis seseorang. Liquid cafe sudah biasa dipenuhi oleh para hedonis, para personil sakadhatu pun cenderung memiliki gaya hidup hedonis. Sakadhatu lebih sering membawakan musik yang bisa mengiringi pengunjung untuk melakukan dance, ini dilakukan karena liquid merupakan ajang yang tepat bagi pengunjung untuk melakukan dance.

Bagi sebagian personil sakadathu dunia malam dan meriahnya musik di liquid café bukanlah suatu hal yang baru mengingat teman-teman mereka di luar pekerjaan juga sudah terbiasa hidup didunia malam, inilah yang dipaparkan oleh vokalis band sakadhatu.

"karena selain lingkungan saya berasal dari dunia malam (teman-teman), upah/gaji yang menggiurkan untuk menjadi vocalist band di club malam, 
selain itu sering mendapat tips dari tamu pengunjung Liquid yang berasal dari kalangan atas".

Fakta lain yang membuat mereka betah bermusik di liquid cafe adalah karena bayarannya yang terbilang besar dari pihak liquid, selain itu personil sakadhatu juga kerap kali mendapatkan tips dari pengunjung papan atas yang dermawan. Kemudahan personil band sakadathu dalam mendapatkan uang dalam bermain musik khususnya di liquid berefek pada ketidakmampuan mereka dalam mengatur keuangan. Gaya hidup personil sakadhatu terbilang boros dan jarang menabung, ini merupakan salah satu efek psikologis negative dari bekerja di dunia malam yang sulit untuk dihindari oleh manusia manapun dimuka bumi ini. Hasil ini menunjukan psikologi perkembangan personil sakadathu cukup terganggu oleh tempat kerja yang memang kurang kondusif untuk menenangkan diri.

Psikologi perkembangan mempelajari faktor-faktor perkembangan manusia sejak lahir hingga pada lanjut usia. Misalnya pembentukan karakter.Seperti yang kita tahu karakter seseorang sangat berbeda-beda. Ada yang keras kepala, pemalu, pemberani, dll. Psikologi perkembangan lebih menjelaskan mengapa karakter-karakter itu bisa ada pada seseorang. Apakah mungkin pada usia kecil dia jarang diperhatikan, jarang diajak komunikasi, atau ketika kecil dia sudah ditunjukkan tentang kekerasan. 


\subsection{Pembahasan}

Dunia malam, diskotik, musik merupakan satu kesatuan yang merupakan waktu dan tempat meraih kesenangan bagi sebagian orang dan tempat mencari sesuap nasi bagi sebagian yang lainnya.bekerja di tempat hiburan apalagi menjadi penghibur utama dalam hal ini grup band sakadhatu tidaklah semulus jalan tol.Butuh kesiapan mental, kondisi psikologis yang baik, kontrol diri yang mumpuni dan yang pasti skill yang memadai untuk tetap eksis didunia malam.

Beberapa anggota grup band sakadhatu mengakui mendapat tantangan dari keluarga atas pilihannya ini, girda vokalis sakadathu mengakui pada awalnya keluar tidak setuju kalau dirinya harus bekerja sebagai penyanyi di liquid café, namun lama kelamaan karena hasilnya mampu membantu ekonomi keluarga yang berada dijakarta akhirnya dan girda dapat meyakinkan keluarganya bahwasannya ia dapat menjaga diri, lambat laun keluarganya memperbolehkan girda untuk bekerja di liquid café sebagai peyanyi. Sekata dengan girda, vintan juga mengalami masalah yang sama dengan girda meskipun akhirnya keluarga mau mengerti.

Fenomena ini menunjukan bahwasanya personil sakadathu yang satu ini mampu meyakinkan orang lain yang awalnya tidak sependapat dengannya. Pemusik tidak cukup hanya bermodalkan suara yang bagus dan skill yang mumpuni saja. Kemampuan dalam mengontrol diri sangat diperlukan untuk menjaga keberlangsungan karirnya.Kontrol diri juga diperlukan saat berada di atas panggung, bagi seorang professional menyanyi bukanlah untuk menghibur dirinya sendiri namun untuk memuaskan pendengar yang memang ingin dipuaskan.Di 
panggung nyanyi tidak perlu benar yang penting pas dengan musik, enak didengar dan dapat menghidupkan suasana.

Minuman beralkohol, bahkan mungkin narkoba kerap kali berada di dalam tempat hiburan malam, pengunjung yang kedapatan mengkonsumsi barang tersebut biasanya lepas control dan melakukan tindakan yang semestinya tidak perlu dilakuan salah satunya ialah mengganggu anggota grup band sakadathu, dari lima personil sakadathu yang paling sering mendapat gangguan adalah vokalis, ketika ini terjadi para personil menegur dengan sopan, jika sudah keterlaluan mereka memarahinya. Fakta ini menunjukan adanya solidaritas yang kuat antar personil sakadathu, inilah yang menjadi grup band ini solid hingga sekarang. 


\section{BAB V}

\section{PENUTUP}

\subsection{Simpulan}

Berdasarkan hasil penelitian di atas diperoleh simpulan sebagai berikut.

Sakadhatu terbentuk November 2011. Sakadathu berarti pondasi, dalam bermusik dan memilih nama yang unik menjadikan mereka lebih unggul dibandingkan dengan band pesaing mereka meskipun mereka sama-sama membawakan musik R\&B sebagai aliran mereka bermusik. Sakadhatu beranggotakan Inu(drum), Pungky (bass), Adhi ( gitar), Vientan (keyboard), Dino, Girda, Helga (vokal). Konsep utama mereka sejak terbentuk adalah menjadi sebuah band longtrip yang solid.

Psikologi para pemain band Sakadathu dalam musik club malam Liquid Semarang dilihat dari gaya bermusik cukup fleksibel. Selera musik yang berbeda dari setiap pemain band Sakadathu membuat para pemain Sakadathu meleburkan idealis masing-masing untuk memberikan sajian musik yang diminta audiens di club malam. Mereka saling melengkapi untuk menutupi kekurangan dalam diri masing-masing. Intigritas pada pekerjaan dan sikap kesetiakawanan antar sesama anggota band sangat dijunjung tinggi, jika salah satu pemain tidak dapat mengontrol diri saat di panggung, pemain lainnya membantu mengatasi masalah yang terjadi pada salah satu personil. Di lain sisi Sakadathu terbilang kurang stabil dilihat dari gaya hidup. Lingkungan sehari-hari yang berinteraksi dengan kalangan 
atas dunia malam, hidupnya cederung menjadi boros dan hedonis. Para pemain tidak bisa mengendalikan diri saat bergaul dengan kalangan atas.

\subsection{Saran}

Berdasarkan hasil penelitian diatas diperoleh saran sebagai berikut.

(1) anggota band sakadhatu khususnya vokalis mengutamakan keselamatan dirinya dalam menghibur pengunjung dengan menjaga jarak aman dari jangkauan penonton saat penguasaaan panggung sehingga pengunjung tetap terhibur dan para personil khususnya vokalis tetap aman terkendali.

(2) Melihat fakta bahwasanya bekerja didunia musik tidak selamanya stabil sebaiknya pemain band Sakadathu mulai membatasi pergaulan dengan kalangan yang dirasakan tidak slalu menguntungkan untuk dirinya sendiri. Sehingga dapat memberi sikap professional sebagai pekerja seni dan mendapat nama baik untuk diri sendiri, orang tua dan orang lain. Serta Sakadathu akan mendapat penghasilan yang memuaskan tanpa adanya pengeluaran yang tidak penting. 


\section{REFERENCES}

Arikunto, Suharsimi, 1994. Prosedur Penelitian : Suatu Pendekatan Praktek. Jakarta : Rineka Cipta. 1998. Metode Penelitian. Jakarta: PT Rineka Cipta

Asikin, Mohammad. 1998. Musik Paradigma Baru Pembelajaran. Makalah Disajikan dalam Seminar Nasional Musik di Jurusan Pendidikan Musik IKIP Yogyakarta, Yogyakarta, 21 April 1988.

Bruner, J. 1960. The Process of Education. Massachusetts: Harvard University Press.

Dahar, Ratna Wilis. 1989. Teori-teori Belajar. Jakarta : Erlangga.

Departemen Pendidikan Nasional. 2000. Pendidikan Seni Musik.Jakarta : Departemen Pendidikan Nasional.

Elearning Pendidikan. Kegiatan Pembelajaran 10 Agustus 2013 [diakses tanggal: 14 Januari 2015] di dapat dari http://www.elearningpendidikan.com/pengertian-kegiatan pembelajaran.html

Gagne, Robert. 1977. The Condition of Learning. New York: Holt.

Hardjana. 2003. Estetika Musik. Jakarta: Dirjen Dikdasmen.

Informasi Pendidikan. Komponen Pembelajaran 25 Januari 2014 [ diakses tanggal 14 Januari 2015 ] di dapat dari http://www.informasipendidikan.com/2014/01/pengertian-dan-macam-macam komponen.html

Jamalus. 1988. Pembelajaran Musik Melalui Pengalaman Musik. Jakarta: Salemba.

Joseph, Wagiman. 2005. Teori Musik I. Semarang: Unniversitas Negeri Semarang

Kagan, Spencer dkk. 2009. Cooperative Learning. Jakarta: PT Gramedia.

Kanisius. 2003. Pengantar Pengetahuan Harmoni. Jakarta: PT Gramedia. 
Koentjaraningrat. 1991. Metode-metode Penelitian Masyarakat. Jakarta : PT. Gramedia.

Ambarwangi, S., \& Suharto, S. (2013). PENDIDIKAN MULTIKULTURAL DI SEKOLAH MELALUI PENDIDIKAN SENI TRADISI. Harmonia: Journal Of Arts Research And Education, 13(1). doi:http://dx.doi.org/10.15294/harmonia.v13i1.2535

Subandi. (2011). Lakon Anoman Duta Garap Padat: Sebuah Penelitian Singkat (The Condensed Creativity of Anoman Duta : A Short Study). Harmonia: Journal Of Arts Research And Education, 6(3). doi:http://dx.doi.org/10.15294/harmonia.v6i3.813

Suharto, S., \& Aesijah, S. (2014). THE LESUNG MUSIC IN THE VILLAGE OF LEDOK BLORA REGENCY. Harmonia: Journal Of Arts Research And Education, 14(1), 65-71. doi:http://dx.doi.org/10.15294/harmonia.v14i1.285

Suharto, S. (2011). Refleksi Teori Kritik Seni Holistik : sebuah Pendekatan Alternatif dalam Penelitian Kualitatif bagi Mahasiswa Seni (Reflection on Art Criticism and Holistic Art Criticism : an Alternative Approach of Qualitative Research for Art Students). Harmonia: Journal Of Arts Research And Education, 8(1). doi:http://dx.doi.org/10.15294/harmonia.v8i1.803

Putra, B. (2013). PENGEMBANGAN MODEL KONSERVASI KESENIAN LOKAL SEBAGAI KEMASAN SENI WISATA DI KABUPATEN SEMARANG. Harmonia: Journal Of Arts Research And Education, 12(2). doi:http://dx.doi.org/10.15294/harmonia.v12i2.2525

Irianto, A. (2016). The Development of Jathilan Performance as an Adaptive Strategy Used by Javanese Farmers. Harmonia: Journal Of Arts Research And Education, 16(1), 38-48. doi:http://dx.doi.org/10.15294/harmonia.v16i1.5213

Hapsari, L. (2014). FUNGSI TOPENG IRENG DI KURAHAN KABUPATEN MAGELANG. Harmonia: Journal Of Arts Research And Education, 13(2). doi:http://dx.doi.org/10.15294/harmonia.v13i2.2780

Ispahani, V. (2012). APRESIASI SEBAGAI SALAH SATU PENDEKATAN DALAM PEMBELAJARAN SENI TARI DI SMP. Harmonia: Journal Of Arts Research And Education, 11(1). doi:http://dx.doi.org/10.15294/harmonia.v11i1.2070 
Budiarti, M. (2011). MENGUBAHÂ CITRA LENGGER MENJADIÂ MEDIA EKSPRESIÂ ESTETIS (To Change the Image of Lengger Into EstheticÂ Medium of Expression). Harmonia: Journal Of Arts Research And Education, 4(2). doi:http://dx.doi.org/10.15294/harmonia.v4i2.708

Darmasti. "TARI SESAJI PANGENTAS BILAHI SUDRA TINGAL." Harmonia: Journal of Arts Research and Education [Online], 12.2 (2012): n. pag. Web. 24 Sep. 2017

Tarwiyah, T. (2011). PELESTARIAN BUDAYA BETAWI PERMAINAN ANAK CICI PUTRI DAN ULABANG/ WAK WAK GUNG : KAJIAN KANDUNGAN KECERDASAN JAMAK. Harmonia: Journal Of Arts Research And Education, 10(1). doi:http://dx.doi.org/10.15294/harmonia.v10i1.51

Tarwiyah, T. (2011). ANALISIS NILAI-NILAI PENDIDIKAN DALAM LAGULAGU DAERAH BETAWI (An Analysis of Educational Values in Songs of the BetawiArea). Harmonia: Journal Of Arts Research And Education, 5(1). doi:http://dx.doi.org/10.15294/harmonia.v5i1.831

Widodo, B. (2011). SLENDRO PELOG: SUATU KETERASINGAN DI DUNIA ANAK. Harmonia: Journal Of Arts Research And Education, 1(1). doi:http://dx.doi.org/10.15294/harmonia.v1i1.837

Widodo, W. (2011). Nuansa Laras Diatonik dalam Macapat Semarangan (Diatonic Scale Atmosphere in Semarang Style Macapat).. Harmonia: Journal Of Arts Research And Education, 7(1). doi:http://dx.doi.org/10.15294/harmonia.v7i1.751

Wiyoso, J. (2011). PENGARUH DIFUSI DALAM BIDANG MUSIK TEHADAP KARAWITAN (The Influence Diffusion of Music to Karawitan). Harmonia: Journal Of Arts Research And Education, 3(2). doi:http://dx.doi.org/10.15294/harmonia.v3i2.687

Wiyoso, J. (2017). Puppet Visual Adaptation on Playing Cards as Educational Media. Harmonia: Journal Of Arts Research And Education, 16(2), 182-191. doi:http://dx.doi.org/10.15294/harmonia.v16i2.5816

Kusumastuti, E. (2011). PENDIDIKAN SENI TARI PADA ANAK USIA DINI DI TAMAN KANAK-KANAK TADIKA PURI CABANG ERLANGGA SEMARANG SEBAGAI PROSES ALIH BUDAYA. 
Harmonia: Journal Of Arts Research And Education, 5(1). doi:http://dx.doi.org/10.15294/harmonia.v5i1.826

Pratjichno, B. (2011). Pornografi dalam Dunia Seni Tari (Pornography in Dance World). Harmonia: Journal Of Arts Research And Education, 7(2). doi:http://dx.doi.org/10.15294/harmonia.v7i2.769

Haryono, S. (2011). DANGDUT DAN EKSPLOITASI SEKS PEREMPUAN (Dangdut and Woman Sex Exploitation). Harmonia: Journal Of Arts Research And Education, 3(2). doi:http://dx.doi.org/10.15294/harmonia.v3i2.688

Budiarti, M. (2011). MENGUBAH CITRA LENGGER MENJADI MEDIA EKSPRESI ESTETIS (To Change the Image of Lengger Into Esthetic Medium of Expression). Harmonia: Journal Of Arts Research And Education, 4(2). doi:http://dx.doi.org/10.15294/harmonia.v4i2.708

Hidajat, R. (2014). The Popularity of Waranggana Tayub Malang through Body Exploitation. Harmonia: Journal Of Arts Research And Education, 14(2), 72-77. doi:http://dx.doi.org/10.15294/harmonia.v14i2.3288

Kustiono. 2013. Teori Belajar dan Implementasinya dalam Pembelajaran. Yogyakarta: Deepublish.

Listiyatiningsih, Ari dkk. 2013. Makalah Metode Penelitian. Salatiga: Universitas Kristen Satya Wacana.

Marwoto, 1987. Musik Drumband. Semarang : BPLP Semarang.

UNS, MB. 2013. MB Sebelas Maret. Surakarta: Universitas Negeri Surakarta

Milles, M. M. Dan Huberman, A. M 1992. Terjemahan T. Rehendi Rosidi. Analisis Data Kualitatif. Jakarta: Universitas Indonesia.

Moleong,J Lexi. 1996. Metode Penelitian Kualitatif. Bandung : PT. Remaja Rosda Karya. Karya. 2000. Metodologi Penelitian Kualitatif. Jakarta: Remaja Rosda Nazir, Moh. 1983. Metode Penelitian. Semarang : Ghalia Indonesia. 
Piaget, J. 1977. The Essential Piaget, ed by Howard E. Gruber and J. Jacques Veneche Gruber. New York: Basic Book.

Prier, K. E. 1991. Sejarah Musik Jilid 1. Yogyakarta : Pusat Musik Liturgi.

Syasi Dwiana, Astari. 2007. Skripsi Pengelolaan Musik Drum Band pada Ekstrakulikuler di SD N 37 Pengambiran. Padang: UNP.

Sinaga, Syahrul. 2000. Beberapa Metode Pengajaran Drumband di Sekolah Taman Kanak - kanak. Semarang : FPBS IKIPSemarang Press.

Skinner, Burrhus Frederic. 2002. Beyond Freedom and Dignity. Jakarta: PT Gramedia.

Soeharto, M. 1992. Pelajaran Seni Musik. Jakarta : PT Gramedia.

Wahyutaji, Tata. 2000. Seni Musik. Jakarta : Yudhistira.

Yusuf, Yasin dkk. 2011. Sirkuit Pintar Melejitkan Kemampuan Matematika dan Bahasa Inggris dengan Metode Ular Tangga. Jakarta: PT Gramedia. 


\section{LAMPIRAN-LAMPIRAN}




\section{PEDOMAN OBSERVASI}

\section{Sasaran Observasi}

a) Gambaran umum Liquid Semarang meliputi:

1. Lokasi, letak, dan kondisi lingkungan.

2. Keadaan pemain band Sakadathu.

3. Bentuk denah dan kondisi lingkungan.

4. Sarana dan prasarana pendukung band Sakadathu di Liquid Semarang.

b) Psikologi para pemain band Sakadathu meliputi:

1. Gaya bermusik

2. Gaya hidup

3. Interaksi pemain band dan penonton 


\section{LEMBAR OBSERVASI}

Observasi penelitian ini dilaksanakan di Liquid café Semarang. Rencana observasi dilakukan tiga kali, berikut rincian observasi :

Observasi 1

Kondisi lingkungan Liquid café Semarang meliputi:
a. Lokasi, letak Liquid café
b. Kondisi lingkungan
c. Bentuk denah Liquid
d. Sarana dan prasarana pendukung band Sakadathu di Liquid Semarang. Observasi 2
a. Wawancara dengan Manager Liquid Semarang
b. Wawancara dengan Manager band Sakadathu
c. Wawancara dengan para pemain Sakadathu

Observasi 3

a. Proses kegiatan pertunjukan di Liquid Semarang

b. Mengambil dokumentasi tentang proses pertunjukan 


\section{PEDOMAN WAWANCARA}

A. Tujuan : Untuk memperoleh informasi tentang gambaran umum

1. Daftar Pertanyaan untuk Manager kafe :

1) Kapan Liquid Semarang didirikan?

- 3 oktober 2009

2) Berikan gambaran tentang denah Liquid Semarang?

- Terletak di jalan Thamrin Square $2^{\text {nd }}$ floor, tepatnya dijalan $\mathrm{MH}$. Thamrin no 5 Semarang

4) Berapa jumlah peagawai Liquid Semarang?

- Kurang lebih sekitar 25 - 30 karyawan, termasuk dengan owner, manager kafe, dan public relation

5) Berapa banyak pengunjung yang datang perminggunya?

- Untuk setiap harinya, kurang lebih 100-200 orang.

6) Prestasi apa yang pernah diraih Liquid dalam beberapa tahun terakhir?

- Liquid setiap minggunya mendatangkan artis papan atas seperti band Geisha, Dewa, Andra and The Backbond dan masih banyak lagi. Kemudian Liquid selalu membuat event-event besar seperti rekor muri penampilan 100 DJ dalam semalam

2. Daftar pertanyaan untuk para pemain band Sakadathu (5 orang) :

1) Apakah jauh atau dekat jarak tempat tinggal dengan Liquid Semarang? 
- Vocal : Dekat, karena saya tinggal di mess yang disediakan Liquid Semarang. Saya sering berpindah-pindah tempat tinggal karena tuntutan pekerjaan sebagai vocalist Longtrip.

- Bassist : Lumayan jauh, karna saya selalu pulang rumah setelah perform di Liquid Semarang. Saya asli bertempat tinggal di Semarang.

- Gitarist : Dekat, karena saya tinggal di mess yang disediakan Liquid Semarang.

- Keyboardist : Jauh, saya menempuh perjalanan dari rumah ke Liquid Semarang sekitar 25 menit dikarenakan saya sudah berkeluarga dan saya asli bertempat tinggal Semarang.

- Drummer : Dekat, karena saya tinggal di mess yang disediakan Liquid Semarang.

2) Berapa durasi waktu band Sakadathu bermain musik di Liquid Semarang?

- All player : Satu sessi 45 menit, Sakadathu diberi kesempatan bermain dua sessi jadi kurang lebih sekitar 2jam .

3) Dari kalangan manakah pengunjung Liquid Semarang?

- All player $\quad$ : Berbeda-beda untuk tiap harinya.

Senin untuk kalangan mahasiswa karena bertema campus party.

Selasa - Sabtu kalangan mahasiswa sampai kalangan atas.

4) Fasilitas apa saja yang diberikan oleh band Sakadathu dari Liquid Semarang?

- All player : Selain diberikan fasilitas alat band yang komplit, Liquid Semarang juga memberikan mess , katering, laundry untuk stiap harinya. 
B. Tujuan : Untuk mengetahui psikologi para pemain band Sakadathu dalam music club malam Liquid Semarang

1. Daftar pertanyaan untuk manager kafe :

1) Apakah band Sakadathu sering dipanggil menjadi home band di Liquid Semarang?

- Sering, karena Sakadathu memiliki kualitas dan kuantitas yang baik untuk menjadi homeband di Liquid Semarang. Pihak Liquid sering melanjutkan kontrak kerja jikalau kontrak dengan Sakadathu sudah habis. Dan kita sudah berjalan dengan Sakadathu selama satu tahun

2) Bagaimanakah kedatangan waktu para pemain band Sakadathu?

- Band Sakadathu merupakan salah satu homeband yang tertib dan disiplin waktu.

3) Bagaimana cara band Sakadathu mengatasi jika terdapat kerusuhan dalam penonton?

- Menghentikan sejenak perform dari Sakadathu agar membuat suasana menjadi kondusif.

4) Mengapa band Sakadathu terpilih menjadi salah satu home band di Liquid Semarang?

- Selain Sakadathu merupakan salah satu band yang berkualitas, mereka mempunyai karakter tersendiri untuk menjadi band longtrip yang pantas berada di Liquid . Kerena untuk diketahui sendiri Liquid merupakan salah satu club terbesar dan ternama di kota Semarang. Disamping itu Sakadathu mempunyai manajer band yang cerdas untuk mempresentasikan profil band Sakadathu. 
5) Fasilitas apa saja yang diberikan oleh band Sakadathu untuk menjadi home band Liquid Semarang?

- Selain alat band yang memadahi untuk menunjang penampilan band Sakadathu, dari Liquid member fasilitas seperti mess, catering makanan, dan laundry.

2. Daftar pertanyaan untuk para pemain band Sakadathu (5 orang):

1) Siapa nama anda?

- Girdha : vocal, 25th

- Pungky : bass, 25th

- Ardhi : gitar, 27th

- Vientan : Keyboard, 26th

- Inu : Drum, 24th

2) Apakah latar belakang pendidikan anda adalah sekolah Musik?

- Girdha : ya , saya dulu pernah bersekolah music di Jakarta

- Pungky : tidak, saya hanya tamatan sma bias tetapi hobi bermusik saya sejak kecil

- Ardhi : tidak, hanya sekedar hobi

- Vientan : tidak, dulu saya sempat ambil les keyboard saat saya sma 
- Inu : tidak, hanya sekedar hobi yang tersalurkan. Saya sering mengikuti festival band saat sma

3) Siapa band yang paling disukai?

- Girdha : Save Ferris

- Pungky : Red Hot Chilli Paper

- Ardhi : Gun's and Roses

- Vientan : John Mayer

- Inu : Dream Theater

4) Genre musik apa yang disukai?

- Girdha : RnB

- Pungky : Funk

- Ardhi : Rock

- Vientan : Blues

- Inu : Rock Progessive

5) Musik apa yang sering dibawakan oleh band Sakadathu di Liquid Semarang?

- Top 40 dan RnB 
6) Musik apa yang sering diminta oleh para pengunjung Liquid Semarang?

- Pop Indonesia dan RnB hits

7) Lagu apa yang paling senang dibawakan diri sendiri?

- Girdha : Rather Be

- Pungky : Uptown Funk

- Ardhi : Can't Remamber to Forget you

- Vientan : If ain't got you

- Inu : Locked out of heaven

8) Apa lagu unggulan band Sakadathu yang sering dibawakan?

All Player :

- She Wolf - Sia ft David Guetaa

9) Apakah alat-alat band yang disediakan oleh Liquid Semarang sudah cukup memadahi?

All Player : Cukup, bila ada yang kurang pemain Sakadathu bisa melengkapi sendiri

10) Apa lagu unggulan band Sakadathu yang sering dibawakan di Liquid Semarang?

- RnB Hits seperti Titanium, Roar, Maps, Sugar 
11) Berapa lama anda bergabung dengan band Sakadathu?

- Girdha : 1th

- Pungky : 4th

- Ardhi : 2th

- Vientan : 4th

- Inu : 4 th

12) Apa alasan anda ingin menjadi pemain band club malam di Liquid Semarang?

- Girdha : karena selain lingkungan saya berasal dari dunia malam (teman-teman), upah/gaji yang menggiurkan untuk menjadi vocalist band di club malam, selain itu sering mendapat tips dari tamu pengunjung Liquid yang berasal dari kalangan atas.

- Pungky : Saya ingin menambah pengalaman bermusik saya, upah/gaji menarik, menambah relasi karena banyak bertemu dengan teman kalangan atas.

- Ardhi : Untuk menambah skill bermusik, menambah relasi kemudian gaji/upah yang tinggi.

- Vientan : Upah/gaji yang tinggi dan cukup untuk memenuhi kebutuhan keluarga saya. Karena saya mempunyai satu anak yang baru masuk sekolah tingkat SD. Selain itu juga untuk menambah skill saya bermain keyboard.

- Inu : Upah/gaji yang menarik dengan kebutuhan saya sekarang semaki meningkat, menambah skill drum saya, menambah relasi. 
13) Apakah upah/gaji menjadi pemain band di Liquid Semarang cukup untuk memenuhi kebutuhan sehari-hari?

\section{All Player :}

- Cukup, Liquid memberikan gaji/upah yang lumayan tinggi.

14) Keuntungan apa yang didapatkan menjadi pemain band di Liquid Semarang?

- Girdha : banyak bertemu dengan kalangan atas, secara tidak langsung dapat menaikkan kelas saya dalam bergaul, sering mendapat job bernyanyi diluar Sakadathu.

- Pungky : mendapat banyak teman, menjadi lebih populer dari sebelumnya

- Ardhi : Sering mendapat job bermain musik diluar Liquid, relasi bertambah, wawasan musik saya menjadi luas karena sering adanya permintaan lagu dari para pengunjung.

- Vientan : Sering mendapat job bermain musik diluar Liquid, relasi bertambah, mudah bergaul dengan siapapun, bertambah populer.

- Inu : menambah relasi, mendapat banyak job diluar Liquid, bertambah skill, menjadi popular banyak dikenal orang-orang.

15) Apakah keluarga mendukung anda untuk menggeluti pekerjaan sebagai pemain band di club malam Liquid Semarang?

- Girdha : awalnya tidak setuju, tetapi kian kemari keluarga mendukung karena saya dapat membantu perekonomian keluarga saya yang berada di Jakarta. 
- Pungky : Setuju, karena background keluarga seni. Didalam musik tidak ada batasan.

- Ardhi : Setuju, keluarga mendukung karena saya dapat menambah perekonomian keluarga.

- Vientan : Awalnya tidak setuju, tetapi saya memberi pengertian kepada istri saya karena dengan menjadi pemain homeband Liquid dapat memenuhi kebutuhan keluarga.

- Inu : Sangat setuju, karena dengan saya mengambil keputusan untuk bekerja seperti ini saya menjadi lebih mandiri dan keluarga bangga karena saya sudah dapat mencukupi kebutuhan sendiri

16) Bagaimana tindakan-tindakan anda jika salah satu pengunjung berbuat tidak sopan terhadap anda?

All Player :

- Saya menegur dengan sopan, jika sudah keterlaluan saya memarahinya dan teman-teman Sakadathu juga biasanya menolong saya jika hal yang tidak sopan itu terjadi.

17) Bagaimana tindakan anda dalam menghadapi pengunjung yang membuat kerusuhan saat band Sakadathu perform?

All Player :

- Sakadathu akan langsung dengan sejenak menghentikan musik untuk membuat suasana menjadi kondusif dan lebih baik. 
LAMPIRAN FOTO-FOTO

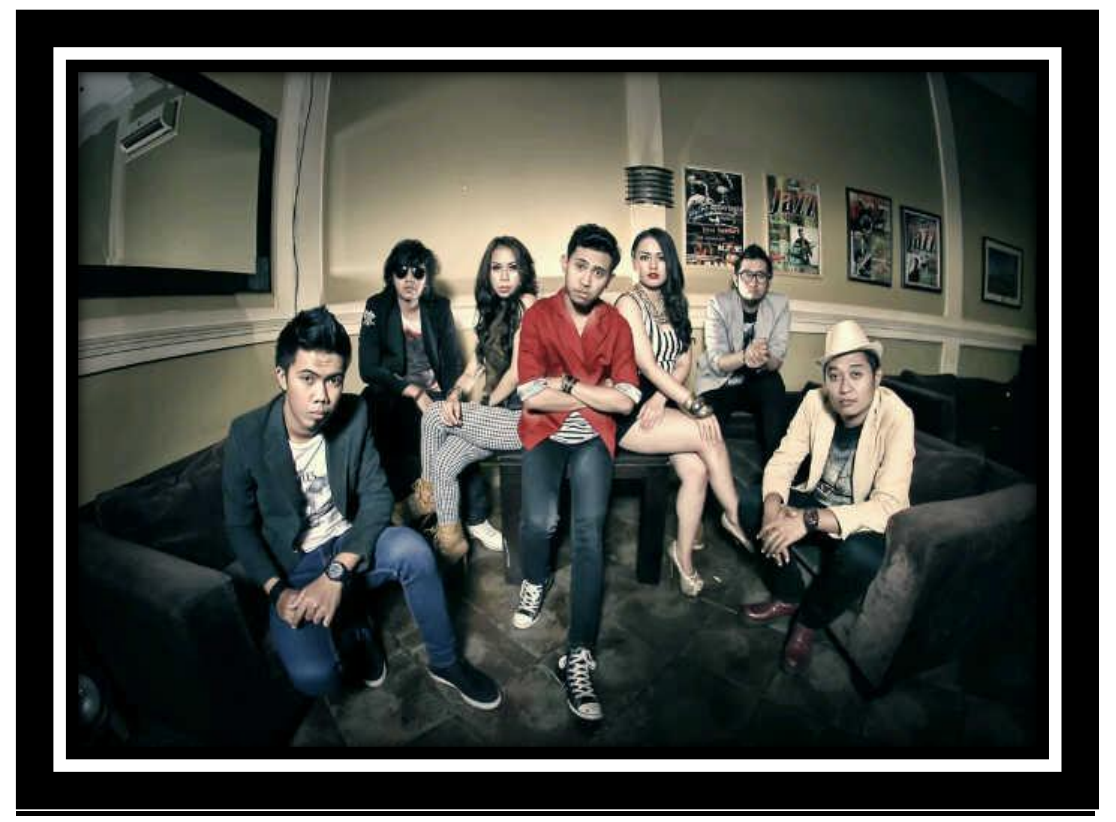

Gambar 1. Profil band Sakadathu

( Foto, Ajeng juni 2015)

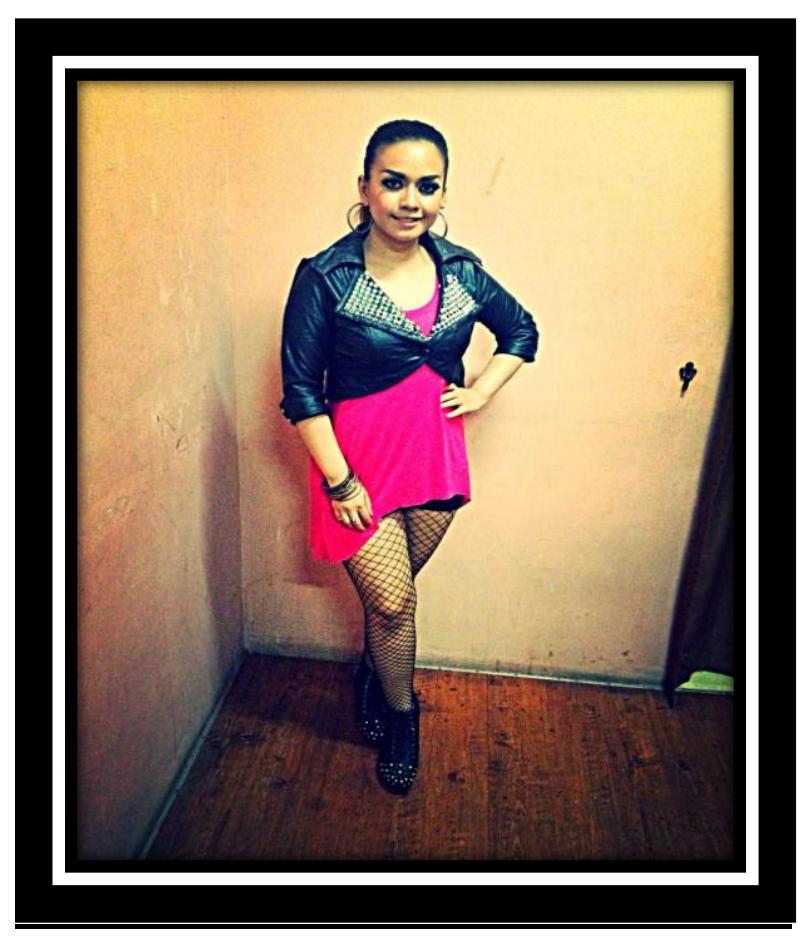

Gambar 2. Girdha vokalis I band Sakadathu ( Foto, Ajeng juni 2015) 


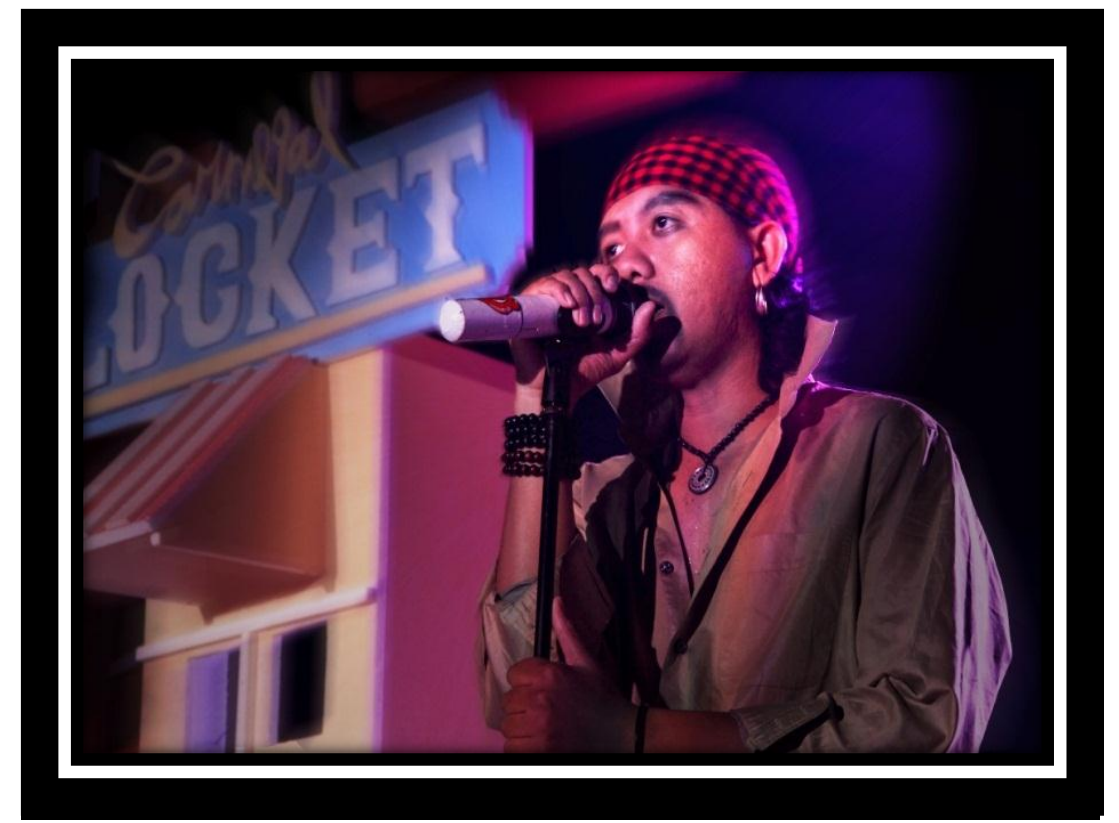

Gambar 3. Dino Adi Vokalis II band Sakadathu

(Foto, Ajeng juni 2015)

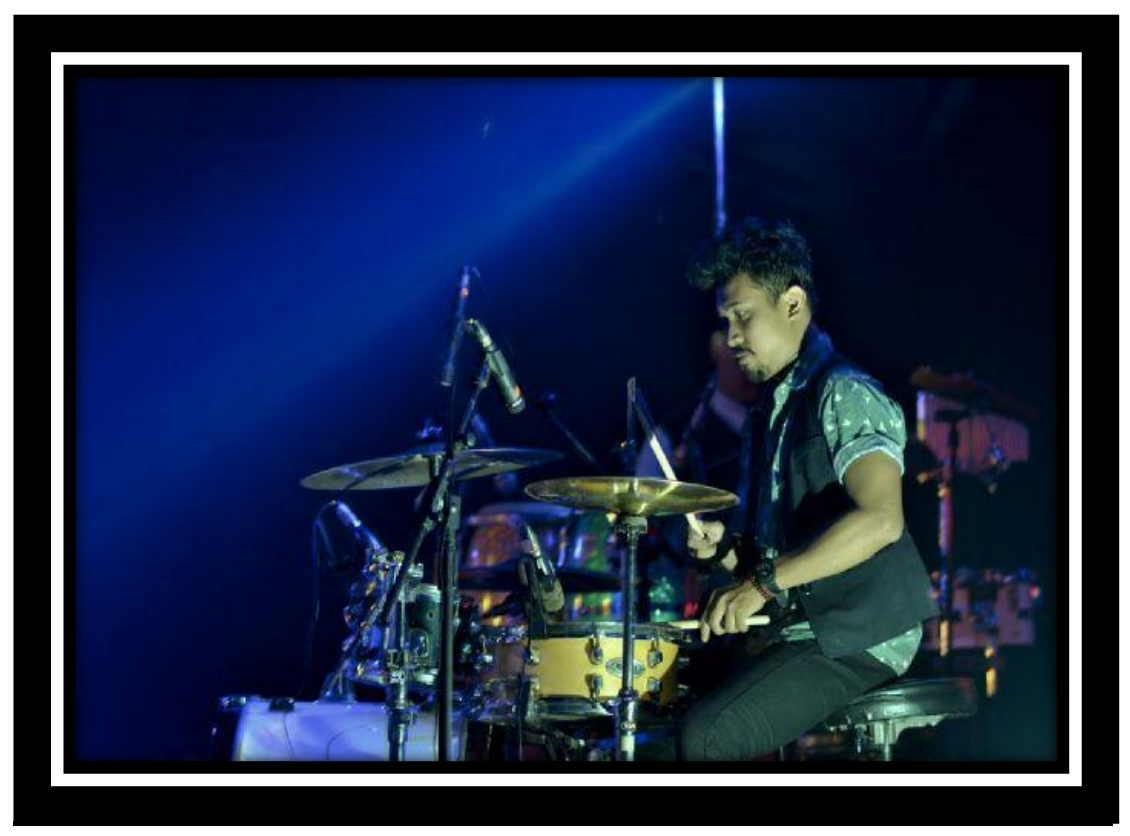

Gambar 4. Lazuardy Wisnu Bahtiar Drummer band Sakadathu ( Foto, Ajeng juni 2015) 


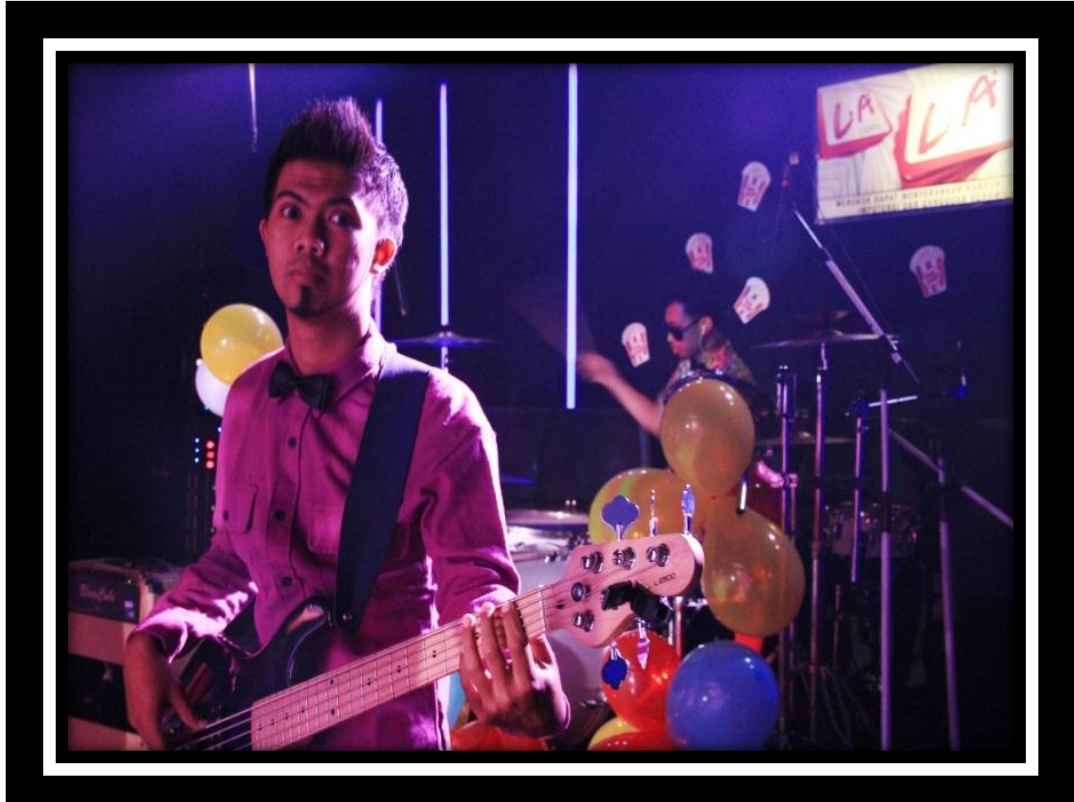

Gambar 5. Pungky Tri Cahyono bassistr band Sakadathu ( Foto, Ajeng juni 2015)

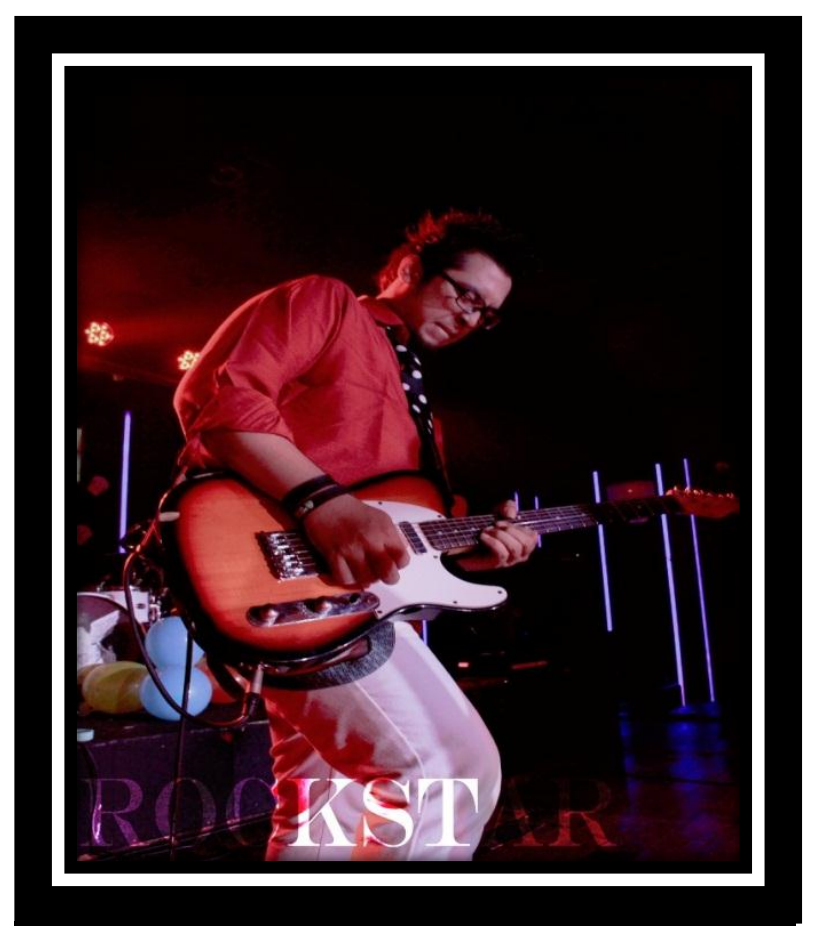

Gambar 6. Kidung Ardhi Gitarist band Sakadathu ( Foto, Ajeng juni 2015) 


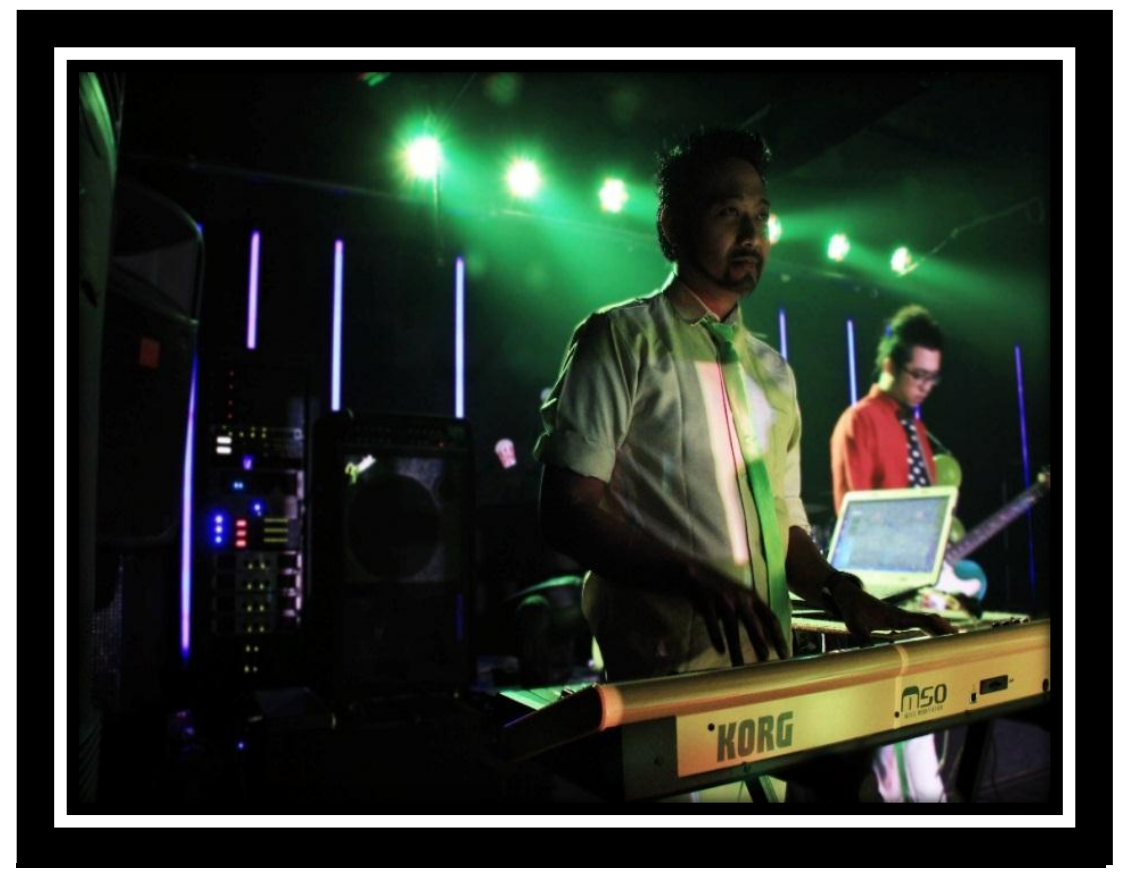

Gambar 7. Vientan Keyboardist band Sakadathu ( Foto, Ajeng juni 2015)

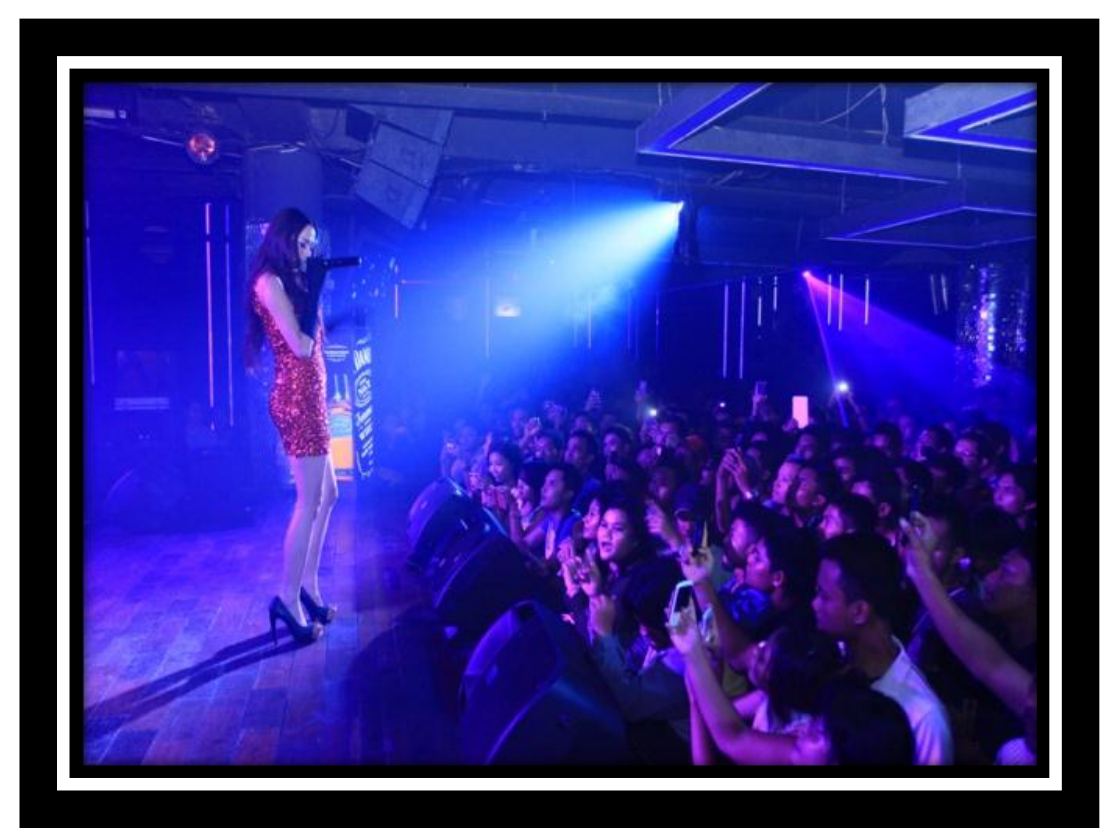

Gambar 8. Interaksi vokalis (Girdha) dengan penonton ( Foto, Ajeng juni 2015) 


KEMENTERIAN RISET, TEKNOLOGI DAN PENDIDIKAN TINGGI
UNIVERSITAS NEGERI SEMARANG
FAKULTAS BAHASA DAN SENI
Gedung B, Kampus Sekaran, Gunungpati, Semarang-50229
Telp. +62248508010 Fax. +62248508010
Laman: http://fbs.unnes.ac.id, Email: fbs@unnes.ac.id

Nomor : 3789/UN37.1.2/LT/2015

Lamp. : -

Hal. : Permohonan Izin Penelitian

Yth. Manager Cafe

di tempat

Dengan hormat kami beritahukan bahwa dalam rangka penyusunan skripsi mahasiswa kami,

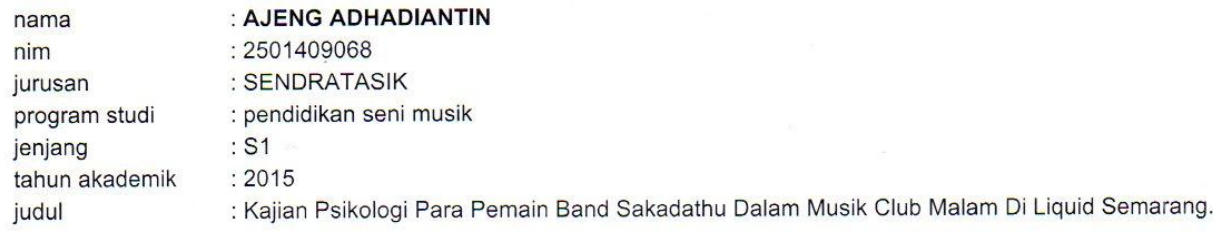

akan mengadakan penelitian di Liquid, waktu pelaksanaan Agustus sd September. Untuk itu kami mohon Saudara berkenan memberikan izin kepada mahasiswa di atas untuk keperluan tersebut.

Atas perhatian dan kerja sama Saudara, kami sampaikan terima kasih.

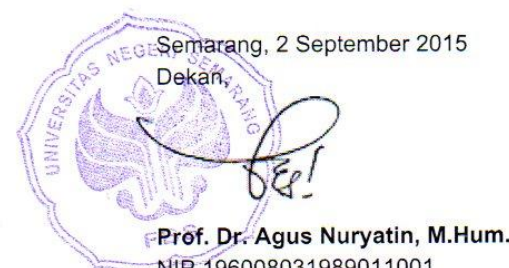

Prôf. Dr. Agus Nuryatin, M.
NIP.196008031989011001

Tembusan:

1. Pembantu Dekan Bidang Akademik

2. Ketua Jurusan

3. Pertinggal

FM-05-AKD-24 


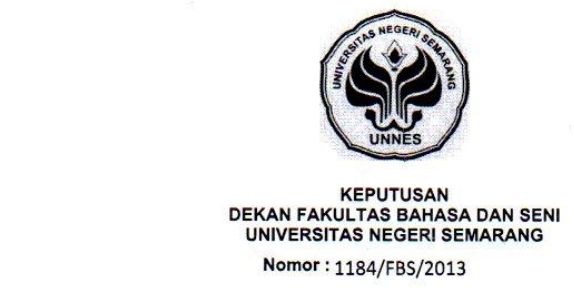

Tentang
PENETAPAN DOSEN PEMBIMBING SKRIPSITUGAS AKHIR SEMESTER GASALGENAP TAHUN AKADEMIK 2012/2013

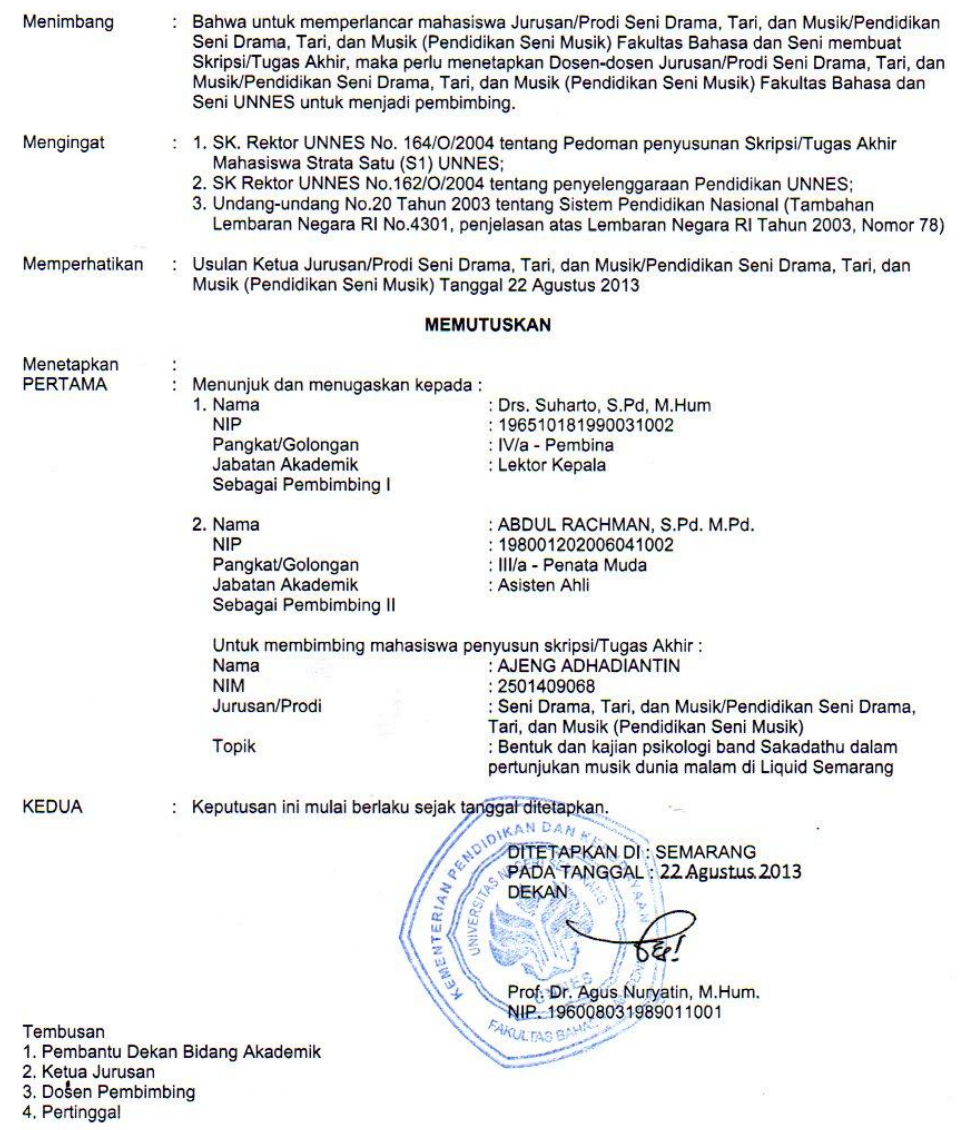

||||||||||||||||||||||| 